\title{
COMMENTS
}

\section{IMPLIED RIGHTS OF ACTION IN FEDERAL LEGISLATION: HARMONIZATION WITHIN THE STATUTORY SCHEME}

The past five years have witnessed a drastic change in the Supreme Court's attitude toward the doctrine of imphed rights of action. In a series of decisions, the Court has imposed severe restrictions on the availability of implied private causes of action under federal statutes. ${ }^{1}$ The Court is not only increasingly reluctant to find additional imphed private actions, but is also deterınined to restrict the scope of existing implied rights of action. An important aspect of this restrictive attitude is the Court's policy that implied actions must be harmonized with those causes of action expressly provided by the federal act. The harmonization pohicy reflects the Court's concern that the effectiveness of procedural and substantive requirenients included in the express cause of action will be circumvented if plaintiffs are permitted to employ an implied cause of action with more relaxed requirements. Thus, even when an imphed private action is deeined necessary to effectuate the legislative purpose, courts must first consider the impact the implied

THE FOLLOWING CITATIONS WILL BE USED IN THIS COMMENT:

1 A. Bromberg, Securities LAw: Fraud (1968), hereinafter cited as A. Bromberg;

Cox, Ernst \& Ernst v. Hochfelder: A Critique and Evaluation of Its Impact Upon the Scheme of the Federal Securities Laws, 28 Hastinas L.J. 569 (1977), hereinafter cited as Cox.

1. The Court's new attitude of restraint in the implication of remedies is one aspect of a larger policy of limiting access to the federal courts. See McMahon \& Rodos, Judicial Implication of Private Causes of Action: Reappraisal and Retrenchment, 80 Dick. L. REv. I67, 177 (1976); Note, Implied Private Actions Under Federal Statutes-The Emergence of a Conservative Doetrine, 18 WM. \& MARY L. Rev. 429, 446 (1976). The Supreme Court has, for exainple, used the standing doctrine to deny judicial remedies to parties seeking to enforce their rights through the federal courts. See Schlesinger v. Reservists Comm., 418 U.S. 208 (1974); United States v. Richardson, 418 U.S. 166 (1974). Similarly, the Court has limited access to the federal courts through the doctrine of justiciability. See Laird v. Tatuın, 408 U.S. 1 (1972); Note, supra, at 446-47. Implicit in the Court's position is a willingness to accept as adequate existing administrative and crimmal statutory enforcement and to withhold statutory remedies even though an ijured plaintiff might be Ieft without a right of action. See notes 20-21 infra. The Court has also denied an imphed private right of action when the cause of action is one traditionally relegated to state law, $m$ an area basically of state concern. Cort v. Ash, 422 U.S. 66, 78 (1975). Sce text accompanymg note 23 infra. 
action will have upon those rights of action expressly included in the statutory scheme.

Lower courts traditionally have been free to formulate their own approaches to determine the proper relationship between express and implied rights of action. These different lower court approaches inust, however, be reevaluated in light of the Supreme Court's recent decisions. This Comment will examine the Court's restrictive policy toward implied rights of action and suggest its likely effect on the various approaches to reconciling express and implied rights of action. The Comment will also suggest a preferred approach for harmonization and will address unresolved issues concerning its implementation.

\section{The Changing Law of Implied Rights of Action}

\section{A. The Development of a Restrictive Attitude Toward Implied Rights of Action.}

1. The Liberal Approach Toward Implying Private Rights of Action. The implication of a private cause of action lias long been recognized as a means of effectuating the overall goals of a statute. ${ }^{2}$ The Supreme Court first imvoked the doctrine of implied reinedies in Texas and Pacific Railway v. Rigsby, ${ }^{3}$ liolding that an injured railroad worker had an implied right of action to sue his employer for dainages under the Federal Safety Appliance Act. ${ }^{4}$ In the fifty years following Rigsby,

2. The doctrine of implied rights of action has been traced to an English case, Couch v. Steel, 118 Eng. Rep. 1193 (Q.B. 1854). See Loss, The SEC Proxy Rules in the Courts, 73 HARV. L. REV. 1041, 1045 (1960). See also Thayer, Public Wrong and Private Action, 27 HARV. L. Rev. 317 (1914). The implied action doctrine was traditionally based on the tort theory of inferring neghgence actions from statutory standards of conduct. Comment, Private Remedies Under the Consumer Fraud Acts: The Judicial Approaches of Statutory Interpretation and Implication, $67 \mathrm{Nw.}$ U.L. REv. 413, 430 n.85 (1972); see RESTATEMENT (SECOND) OF ToRTs $\$ 286$ (1965). The Supreme Court, however, has indicated in recent decisions that the implication of private actions under federal law is a matter of statutory construction. Thus, courts are to determine whether Congress intended to create an imphed action. Transamerica Mortgage Advisors, Inc. v. Lewis, 444 U.S. 11, $15-16$ (1979); Touche Ross \& Co. v. Redington, 442 U.S. 560,575 (1979); Cannon v. University of Chicago, 441 U.S. 677, 689 (1979); see National R.R. Passenger Corp. v. National Ass'n of R.R. Passengers, 414 U.S. 453, 458 (1975). See notes 16-25 infra and accoinpanying text.

The doctrine of implied private actions has been justified as necessary to effectuate the purposes of legislation. Courts are arguably in the best position to ensure the effectiveness of remedial legislation and thus have been viewed as coordinate lawmakers with the legislature. Note, Implying Civil Remedies from Federal Regulatory Statutes, 77 HARv. L. REv. 285 (1963); see Note, Emerging Standards For Implied Remedies Under Federal Statutes, 9 U. MICH. J.L. REF. 294, 296 (1976).

3. 241 U.S. 33 (1916).

4. 45 U.S.C. $\$ \S 1-7,11-15$ (1976). The Rigsby Court found that Congress passed the Safety Appliance Act to protect railroad employees. The Court stated the standard for implying a civil action as follows: "A disregard of the command of the statute is a wrongful act, and where it results in damage to one of the class for whose especial benefit the statute was enacted, the right to recover the damages from the party in default is imphed . . . ." 241 U.S. at 39. 
courts found implied private rights of action in a number of federal statutes. ${ }^{5}$

In the 1960 s the Supreine Court in J.I. Case Co. v. Borak ${ }^{6}$ and Wyandotte Transportation Co. v. United States ${ }^{7}$ formulated a liberal set of standards for finding implied rights of action. Under these standards, the courts were inerely to inquire whcther the existing liability provisions were adequate to effectuate the congressional purpose. ${ }^{8}$ Following this liberal approach, courts frequently found implied rights of action even though the particular plaintiffs could not have sued successfully under the statute itself. ${ }^{9}$

Closely related to the question whether an implied private right of action exists is the issue of the proper scope of that private action once it has been recognized. Courts frequently inust decide whether to extend a previously found cause of action into subsequent cases involving different classes of plaimtiffs or different circuinstances. Generally, as courts expanded the nuinber of inplied rights of action, they also expanded the scope of the private actions that already had been implied. The inost prominent example of this expansion was the implied right of action for violations of section 10(b) of the Securities Excliange Act of

5. See, e.g., Euresti v. Stenner, 458 F.2d 1115 (10th Cir. 1972) (right of action implied under Hill-Burton Act, 42 U.S.C. $\$ 291$ (1976)); Like v. Carter, 448 F.2d 798 (8th Cir. 1971) (right of action implied under the Social Security Act, 42 U.S.C. $\$ 301-1396 \mathrm{~g}$ (1976)), cert. denied, 405 U.S. 1045 (1972); Gomez v. Florida State Employment Serv., 417 F.2d 569 (5th Cir. 1969) (migrant workers who accepted employment through employment system established by the WagnerPeyser Act of 1933, 29 U.S.C. $\$ 49$ (1976), held entitled to civil remedies for violations of the Act); Fitzgerald v. Pan Am. World Airways, 229 F.2d 499 (2d Cir. 1956) (private right of action for racial discrimination implied under section 1374(b) of the Federal Aviation Act, 49 U.S.C. $\$ 8$ 484(b), 622(a), 676 (1976)); Guernsey v. Rich Plan of the Midwest, 408 F. Supp. 582 (N.D. Ind. 1976) (implied right of action under Federal Trade Commission Act, 15 U.S.C. $\$ \S 41-77$ (1976)); Kardon v. National Gypsum Co., 69 F. Supp. 512 (E.D. Pa. 1946) (implied remedy under section 10(b) of the Securities Exchange Act of 1934, 15 U.S.C. \& 78j(b) (1976)).

6. 377 U.S. 426 (1964). In Borak, the Court found an implied right of action under section 14(a) of the Securities Exchange Act of 1934, 15 U.S.C. $\$ 78$ n(a) (1976). Section 14(a) makes the use of false or misleading proxy statements illegal.

7. 389 U.S. 191 (1967). In Wyandotte, the Court stated that the criminal sanction of section 15 of the Rivers and Harbors Act of 1899, 33 U.S.C. $\S 409$ (1976), which proscribes the negligent sinking of a ship in a navigable waterway, was not the exclusive remedy under the statute. The Court held that the United States could bring a civil action to recover from the owner the costs of removing the vessel.

8. In Borak, the Court emphasized the Exchange Act's broad remedial purposes, finding private enforcement to be "necessary to make effective the congressional purpose." 377 U.S. at 433. In Wyandotre, the Court clarified the essential factors in determining whether to imply a private right of action: (1) whether the interests of the plaintiff were within the class protected by the statute; (2) whether the harn that had occurred was of the type the statute was intended to prevent; and (3) whether criminal liability was adequate to ensure the effective enforcement of the statute. 389 U.S. at 202.

9. See text accompanying notes $66-68$ infra. 
$1934^{10}$ and rule $10 \mathrm{~b}-5,{ }^{11}$ promulgated under that section. Section $10(\mathrm{~b})$ and rule $10 \mathrm{~b}-5$, which prohibit the use of any manipulative device or contrivance in connection with the purchase or sale of a security, were first held to give rise to an imphed cause of action in Kardon v. National Gypsum Co. ${ }^{12}$ In Kardon, the court found an implied private action under rule 10b-5 for material misrepresentations that induce the sale of securities. In the years following Kardon, federal courts expanded the scope of the inplied action under section $10(\mathrm{~b})$ and rule 10b-5 to allow suits in a wide variety of situations. ${ }^{13}$ This expansion permitted suits

10. 15 U.S.C. $\$ 78 \mathrm{j}(\mathrm{b})$ (1976). The Act provides:

\& 78j. Manipulative and deceptive devices.

It shall be unlawful for any person, directly or indirectly, by the use of any means or instrumentality of interstate commerce or of the mails, or of any facility of any national securities exchange-

(b) To use or employ, in connection with the purchase or sale of any security registered on a national securities exchange or any security not so registered, any manipulative or deceptive device or contrivance in contravention of such rules and regulations as the Commission may prescribe as necessary or appropriate in the public interest or for the protection of investors.

Id.

11. 17 C.F.R. $\$ 240.10 b-5$ (1980). The rule provides:

It shall be unlawful for any person, directly or indirectly, by the use of any means or instrumentality of interstate commerce, or of the mails or of any facility of any national securities excliange,

(a) To employ any device, scheme, or artifice to defraud,

(b) To make any untrue statement of a inaterial fact or to omit to state a material fact necessary in order to make the statements made, in the light of the circumstances under which they were made, not misleading, or

(c) To engage in any act, practice, or course of business which operates or would operate as a fraud or deceit upon any person, in connection with the purchase or sale of Id. any security.

12. 69 F. Supp. 512 (E.D. Pa. 1946).

13. See, e.g., Affiliated Ute Citizens v. United States, 406 U.S. 128, 156-57 (1972) (private action implied under rule $10 \mathrm{~b}-5$ for injury caused by misrepresentation of material fact; the plaintiff was not required to show that he relied on those facts); Superintendent of Ins. v. Banker's Life \& Cas. Co., 404 U.S. 6, 13-14 (1971) (right of action implied under rule 10b-5 for scheme to purchase shares with ultiinately worthless assets); Shapiro v. Merrill Lynch, Pierce, Fenner \& Smith, Inc., 495 F.2d 228 (2d Cir. 1974) (private rule 10b-5 action for insider, tipper, and tippee use of nonpublic material information); White v. Abrams, 495 F.2d 724, 736 (9th Cir. 1974) (rule $10 \mathrm{~b}-5$ violated by material inisrepresentations regarding promissory notes, even if defendant unaware that statements were false); Eason v. General Motors Acceptance Corp., 490 F.2d 654, 66061 (7th Cir. 1973) (shareholders of corporation purcliasing car-leasing busimess with newly issued stock may sue under rule 10b-5, even though not purchasers or sellers of stock), cert. denied, 416 U.S. 960 (1974); Mitchell v. Texas Gulf Sulphur Co., 446 F.2d 90 (10th Cir.) (private action for misrepresentations and omissions of material facts in written press release), cert. denied, 404 U.S. 1004 (1971); Pappas v. Moss, 393 F.2d 865 (3d Cir. 1968) (private right of action under rule 10b-5 for corporate mismanagement-corporate directors' sale of corporation's stock to themselves).

The decisions in White v. Abrams and Eason v. Gcneral Motors Acceptance Corp. are now questionable in light of Ernst \& Ernst v. Hochfelder, 425 U.S. 185 (1975), and Blue Chip Stamps v. Manor Drug Stores, 421 U.S. 737 (1975), respectively. See notes 35-48 infra and accompanying text. 
by many plaimtiffs who otherwise would have been prevented from bringing actions under any of the express liability provisions ${ }^{14}$ of the securities laws. ${ }^{15}$

\section{Recent Limitations on Finding Implied Private Rights of Action.} Since 1975 the Burger Court's decisions have indicated a retreat from the liberal attitude of the Borak-Wyandotte era and a more restrictive approach toward implied riglits of action. For example, in National Railroad Passenger Corp. v. National Association of Railroad Passengers (Amtrak), ${ }^{16}$ the Court refused to recognize a private right of action under the Rail Passenger Service Act of $1970 .{ }^{17}$ In decidimg whether to find a private right of action, the Amtrak Court did not look solely to the harm the statute was intended to prevent or to the adequacy of existing remedies. Rather, the Court emphasized the necessity of determining whether Congress specifically intended to grant a private right of action to persons in the particular circuinstances of the plaintiffs. To ascertain Congress's intent, the Court invoked the restrictive maxim of statutory construction, expressio unius est exclusio alterius, ${ }^{18}$ and imterpreted a section of the Amtrak Act providing for enforcement by the Attorney General as a sign of congressional intent to preclude all other remedies. The Court also found support for its conclusion in the legislative history and the purpose of the Rail Passenger Service Act. ${ }^{19}$

14. There are three express liabihity provisions in the Securities Act of 1933: section 11, 15 U.S.C. $\$ 77 \mathrm{k}(1976)$, which provides a reinedy for persons buying a security when a registration statement is misleading on the date it becomes effective; section 12(1), 15 U.S.C. $\$ 77 /(1)$ (1976), which provides a renedy when the sale of securities is not registered but should be; and section $12(2)$, 15 U.S.C. $\$ 77 /(2)$ (1976), whicl permits an action where securities are purchased on the basis of a misleading representation. See A. JACOBS, THE IMPACT OF Rule 10b-5 $\$ 3.01$ (rev. ed. 1979). The Securities Exchange Act of 1934 also provides three clear express liability provisions: section 9 (e), 15 U.S.C. $\$ 78 \mathrm{i}(\mathrm{e})$ (1976), confers a private right of action against a party who has willfully engaged in inarket inanipulation; section 16(b), 15 U.S.C. \&78p(b) (1976), permits an issuer to bring an action for disgorgennent of all insiders' short swing profits; and section 18(a), 15 U.S.C. $\$ 78 \mathrm{r}(\mathrm{a})(1976)$, provides a private right of action to investors who have been defrauded by relying on documents filed with the SEC.

15. See text accoinpanying notes $66-68$ infra.

16. 414 U.S. 453 (1974).

17. 45 U.S.C. $\$ \$ 501-650$ (1976). The Act prohibited discontinuance of passenger trains prior to January 1, 1975 unless the railroad had entered into a contract with Amtrak under which Amtrak would take over the railroad's responsibility for intercity passenger rail service. Section 307 of the Act provides for enforcement suits by the Attomey General or, in cases involving a labor agreement, by employees or their representatives. Id. $\$ 547$.

18. The expression of one thing is the exclusion of another.

19. According to the Court, the expressio unius maxim would yield to clear evidence of contrary legislative intent. The Court, however, found evidence in the legislative history of an intent to deny private actions other than those specifically authorized by the Act. 414 U.S. at 461 . Although the Court concluded that implication would be contrary to the legislative intent, it also considered whether an implied private action would be consistent with the legislative purpose. 
In subsequent decisions the Supreme Court has continued to apply the implication doctrine restrictively. ${ }^{20}$ The Court has consistently ignored the question of whether an injured plaintiff has an adequate remedy under a statute and instead continues to stress the necessity of divining congressional intent at the time of enactment. ${ }^{21}$ This concern for Congress's intent is central to the Supreme Court's first comprehensive implication test, formulated in Cort v. Ash. ${ }^{22}$ In that case the Court listed four factors to be considered in determining whether to imply a private right of action:

First, is the plaintiff "one of the class for whose especial benefit the statute was enacted," . . . that is, does the statute create a federal right in favor of the plaintiff? Second, is there any indication of legislative intent, explicit or implicit, either to create such a remedy or to deny one? . . . Third, is it consistent with the underlying purposes of the legislative scheme to imply such a remedy for the plaintiff? . . . And finally, is the cause of action one traditionally relegated to state law, in an area basically the concern of the states, so that it would be inappropriate to infer a cause of action based solely on federal law?23

Although the Cort test breaks down into four criteria, it is essentially a three-part inquiry, insofar as the Court saw the first two criteria

Again relying on the legislative history, the Court found that the purpose of the Act was to preserve passenger train service and noted that one method of achieving the Act's purpose was the quick and efficient elimination of unprofitable routes. According to the Court, allowing private actions to enjoin proposed discontinuances would inpede the process to be used in the paring of unprofitable routes. $I d$. at 463.

20. E.g., Transamerica Mortgage Advisors, Inc. v. Lewis, 444 U.S. 11 (1979) (expressio unius invoked to deny implied private action under section 206 of the Investunent Advisors Act of 1940, 15 U.S.C. \$ 80b-6 (1976)); Touche Ross \& Co. v. Redington, 442 U.S. 560 (1979) (no implied private action under section 17(a) of Securities Exchange Act of 1934, 15 U.S.C. 8 78q(a) (1976)); Cort v. Ash, 422 U.S. 66 (1975) (no imphed private action under Federal Election Campaign Act of 1971, 18 U.S.C. $\$ 610$ (1970) (repealed 1976)); Securities Investor Protection Corp. v. Barbour, 421 U.S. 412 (1975) ( $A$ mtrak followed; Court reluctant to imply private action since section 7(b) of Securities Investor Protection Act of 1970,15 U.S.C. $\$ 78 \mathrm{ggg}($ b) (1976), provided administrative remedy).

21. In Securities Investor Protection Corp. v. Barbour, 421 U.S. 412 (1975), the Court found no indication of congressional intent to permit an implied right of action under the Securities Investor Protection Act. The Court thus denied plaintiffs an implied private action even though it meant that the only remedy under the Act was that the Securities and Exchange Commission could sue in federal court. Similarly, in Cort v. Ash, 422 U.S. 66 (1975), the Court found no evidence of a legislative intent to permit a private right of action under the Federal Corrupt Practices Act of 1925 as amended by the Federal Election Campaign Act of 1971, 18 U.S.C. $\$ 610$ (1970) (repealed 1976). The statute prohibited the use of corporate funds in federal pohtical campaigns. The holding in Cort left only criminal sanctions under the Act, and potential state law claims.

22. 422 U.S. 66 (1975).

23. Id. at 78 (citations omitted). 
merely as reliable indicators of Congress's intentions. ${ }^{24}$ The inclusion of the second criterion in Cort reaffiruns the Court's insistence on using legislative history to determine legislative intent. Therefore, a finding that Congress intended to deny a private cause of action disposes of the inplication question. ${ }^{25}$ In its decisions since Cort v. Ash, the Supreme Court has placed almost total rehance on discerning the legislative intent as inanifested in the statutory language and in the statute's legislative history. ${ }^{26}$ The Court has only occasionally utilized the four-

24. The four-pronged Cort test's only significant addition to the standards used in Amtrak is thus the state concern factor. See Comment, Implying Private Causes of Action from Federal Statutes. Cort and Amtrak Apply the Brakes, 17 B.C. InDus. \& Com. L. Rev. 53, 62 (1975).

25. 422 U.S. at $82-83$. Most lower court decisions applying the Cort test have denied private rights of action. E.g., Wentworth v. Solem, 548 F.2d 773 (8th Cir. 1977) (no cause of action implied under criminal statute dealing with transportation and labeling of goods made in prisons, 18 U.S.C. $\S \S 176 \mathrm{l}, 1762$ (1976)); Rauch v. United Instruments, Inc., 548 F.2d 452 (3d Cir. 1976) (no implied action under section 601 and other provisions of the Federal Aviation Act of 1958, 49 U.S.C. $\$ 1421$ (1976)); Jaillet v. Hill \& Hill, 460 F. Supp. 1075 (W.D. Pa. 1978) (no implied action under section 202(a) of the Federal Water Pollution Control Act, 33 U.S.C. $\$ 1282$ (a) (1976)); Rogers v. Frito-Lay, Inc., 433 F. Supp. 200 (N.D. Tex. 1977) (no implied action under section 503 of Rehabilitation Act of 1973, 29 U.S.C. $\$ 793$ (1976)). Nevertheless, the Cort test also has been used to imply private remedies. E.g., Leist v. Simplot, No. 79-7402 (2d Cir., July 8, 1980) (Commodity Exchange Act, 7 U.S.C. $\$ \S 1-19$ (1976)); Riggle v. California, 577 F.2d 579, 583 (9th Cir. 1978) (Rivers and Harbors Appropriation Act of 1906, 33 U.S.C. $\$ 401$ 1976)); Abrahainson v. Fleschner, 568 F.2d 862 (2d Cir. 1977) (section 206 of the Investment Advisors Act of 1940, 15 U.S.C. \& 80b-6 (1976)), cert. denied, 436 U.S. 913 (1978); United Handicapped Fed'n v. Andre, 558 F.2d 413 (8th Cir. 1977) (section 504 of Reliabilitation Act of 1933, 29 U.S.C. $\$ 794$ (1976)).

26. See Leist v. Simplot, No. 79-7402, slip op. at 4092 (2d Cir., July 8, 1980) (Friendly, J.) (the Supreme Court's recent decisions indicate that congressional imtent is the "ultimate toucl-stone" in implymg causes of action from federal statutes). There are strong indications that the majority of the Supreme Court no longer considers the Cort standards restrictive enough. In several recent decisions, the Court has returned to its more restrictive Amtrak approach, placing total emphasis on discerning the legislative intent, as manifested in the statutory language and in the legislative history. E.g., Transaunerica Mortgage Advisors, Inc. v. Lewis, 444 U.S. 11 (1979); Toucle Ross \& Co. v. Redington, 442 U.S. 560 (1979). Cf. Carlson v. Green, 100 S. Ct. 1468, 1478 (1980) (Rehnquist, J., dissenting); Cannon v. University of Clicago, 44I U.S. 677, 749 (1979) (Powell, J., dissenting) (Cort test permits implication too readily; courts slould not condone implication "absent the most compelling evidence the Congress in fact intended such an action to exist").

Although the Transamerica Court found that section 215 of the Investment Advisors Act of 1940 , 15 U.S.C. $\$ 80$ b-15 (1976), gave rise to a himited implied remedy, the Court reached this conclusion only because the statutory language implied that a limited right of action was intended. 444 U.S. at 18-19. In Redington, the Court denied an implied right of action under section 17(a) of the Securities Exchange Act of 1934, 15 U.S.C. $\$ 78 \mathrm{q}(\mathrm{a})$ (1976), discerning no evidence of a legislative imtent to permit such an action in the statutory language or in the legislative history of section 17(a). Transamerica and Redington also marked the resurrection of the expressio unius rule, which the Court had not invoked since before Cort $v$. Ash. See note 18 supra and accompanying text. In Transamerica, the Court relied on the maxim in denying an implied cause of action under section 206 of the Investment Advisors Act of 1940. 444 U.S. at 19-20. In Redington, the Court used the maxim as support for its decision denying an implied private action under section 17(a) of the Securities Excluange Act of 1934. Transamerica also makes apparent a second indication of the Court's increasing restrictiveness. The Court found a limited implied right of action, 
pronged test of Cort $v$. Ash. ${ }^{27}$

Recently the Court indicated that before finding an implied private riglit of action froin a federal statute it will also consider the likely impact of an implied private action upon the statutory scheme. In Touche Ross \& Co. v. Redington, ${ }^{28}$ the Court held that section 17(a) of the Securities Exchange Act, ${ }^{29}$ which requires broker-dealers and others to keep such records and file such reports as the Securities and Exchange Commission may prescribe, does not create a private cause of action. The principal basis for the Court's holding was the absence of any language in section 17(a) indicating that Congress intended to create private rights of action. ${ }^{30}$ The Court also justified its holding, however, by examining section 17(a) within the statutory scheme of the securities laws. Notmg that section 17(a) is flanked by provisions of the Securities Exchange Act that expressly grant private causes of action, ${ }^{31}$ the Court found, through what amounted to the use of the expressio unius rule, that the existence of these express remedies militated against implication. ${ }^{32}$ The Court also reasoned that to permit a plaintiff to pro-

restricting available relief to contract recission, injunctive relief or restitution. Id. at 18-20. Just the previous term, in Davis v. Passman, 442 U.S. 228 (1979), the Court had recognized that "the question whether a hitigant has a 'cause of action' is analytically distinct and prior to the question of what relief, if any, a litigant may be entitled to receive." Id. at 239.

27. The Court is adopting a very pragmatic, nonuniform approach. In essence, it uses whatever process of reasoning is necessary to achieve the desired result. See Lowenfels, Recent Supreme Court Decisions Under The Federal Securities Laws: The Pendulum Swings, 65 Geo. L.J. 891 (1977). In Transamerica, the Court never mentioned the Cort test, while in Cannon v. University of Chicago, 441 U.S. 677 (1979), the Court relied exclusively on the Cort standards in reaching what was virtually a foregone conclusion. In Cannon, the Court imferred a right of action under section 901(a) of Title IX of the Education Amendments of 1972, 20 U.S.C. \& 1681(a) (1976). The language in Title IX is very similar to the language in section 5 of the Voting Rights Act of 1965, 42 U.S.C. $\$ 1973 \mathrm{c}$ (1976), from which the Court had previously inferred a private remedy in Allen v. State Bd. of Elections, 393 U.S. 544, 554-55 (1969). Instead of overruling Allen, the Cannon Court utilized a straight Cort analysis and inferred a cause of action from Title IX. 44 I U.S. at $689-90$.

One may also hypothesize that to a great extent the Court's recent decisions depend upon who is the writer of the opinion. When an opinion is written by a justice opposed to implied actions, having a different starting point in the first draft stage, there often results slightly different language than if the opinion is drafted by a proponent of implied rights of action.

28. 442 U.S. 560 (1979).

29. 15 U.S.C. $\& 78 q$ (a) (1976).

30. 442 U.S. at 568-69. According to the Court, section 17(a) was designed to provide protection for brokers' customers and did not require that a private damage action be implied on their behalf. $I d$, at 578-79.

31. Section 16(b), 15 U.S.C. § 78p(b) (1976); section 18(a), 15 U.S.C. \& 78r(a) (1976); section 9(e), 15 U.S.C. $\$ 78 \mathrm{i}(\mathrm{e})$ (1976).

32. 442 U.S. at 571-72. The Court invoked the reasoning it used in Blue Chip Stamps v. Manor Drug Stores, 421 U.S. 723, 734 (1975): "When Congress wished to provide a damage remedy, it knew how to do so and did so expressly." 442 U.S. at 572 . See notes $35-42$ infra and accompanying text. 
ceed under section 17 (a) would disrupt the statutory scheme. Section 18(a) of the Exchange Act, for example, expressly creates a private cause of action against persons making materially misleading statements in reports filed with the Securities and Exchange Commission. ${ }^{33}$ Protection under section 18(a), however, extends only to persons who, in reliance on the statements, purchased or sold a security at a price that was influenced by the statements. In Redington there was no allegation that the injured party had purchased or sold securities im reliance on the section 17(a) reports. The Court found that to permit a section 17(a) action would nullify the requirements for a section 18(a) suit. ${ }^{34}$

3. Recent Restrictions on the Scope of Previously Recognized Implied Rights of Action. Since the mid-1970s, the Supreme Court has also adopted a restrictive attitude toward the extension of previously recognized implied rights of action. For example, the Court has placed significant limitations upon the scope of the implied right of action under section 10(b) and rule 10b-5. In Blue Chip Stamps v. Manor Drug Stores, ${ }^{35}$ the Court upheld the rule of Birnbaum v. Newport Steel Corp. ${ }^{36}$ whicl limits standing under the section 10 (b) and rule 10b-5 implied right of action to persons who have been defrauded im connection with their own purchase or sale of securities. ${ }^{37}$ In reaching its decision, the Court observed that Congress had rejected a proposed amendment to section 10(b) to change its wording from "in connection with the purchase or sale of any security" to "in connection with the purchase or sale of or any attempt to purchase or sell any security." 38 The Court regarded this modicum of legislative history as evidence that

33. 15 U.S.C. \& 78r(a) (1976).

34. According to the Court: "[W]here the principal express civil remedy for misstatements in reports [section 18] . . . is by its terms limited to purchasers and sellers of securities, we are extreinely reluctant to imply a cause of action in $\$ 17$ (a) that is significantly broader than the remedy that Congress cliose to provide." 442 U.S. at 574.

The Court also took note of evidence in the legislative history that section 18(a) was intended to be an exclusive remedy for misstatements filcd with the SEC, though it did not decide the question. Id.

35. 421 U.S. 723 (1975). In Blue Chip, a nonpurchasing offeree of Blue Chip Stamp Company Securities brought suit under section $10(b)$ and rule $10 b-5$. The prospectus containing the offer of Blue Chip stock was pessimistic in its appraisal of the offeror's status and of future prospects. The plaintiff alleged that the prospectus was materially misleading and designed to discourage the plaintiff and other offerees from buying the shares at a bargain price. The plaintiff also alleged that the offeror was able, as a result, to sell the securities to the general public at a higher price.

36. 193 F.2d 461 (2d Cir.), cert. denied, 343 U.S. 956 (1957).

37. 421 U.S. at 754-55.

38. Id. at 732 (citing 103 Cong. Rec. 11636 (1957)) (enphasis added by the Court). 
Congress intended to limit the benefits of the section 10(b) implied private right of action to actual purchasers and sellers. ${ }^{39}$

The Court in Blue Chip Stamps also looked, however, to the statutory scheme, noting that the express liability provisions of the 1934 Act and of the Securities Act of 1933 were limited to purchasers and sellers of securities and were enacted contemporaneously with section $10(\mathrm{~b}) .^{40}$ From this limitation the Court reasoned that Congress could not have intended to create a broader class of plaintiffs in an implied cause of action than it had created under the express liability sections. ${ }^{41}$ Under Blue Chip Stamps, therefore, the purpose and the scope of the express liability sections were criteria used in establishing the contours of the implied right of action. ${ }^{42}$

Less than a year after Blue Chip Stamps, the Supreine Court decided Ernst \& Ernst v. Hochfelder. ${ }^{43}$ Again, the Court imposed a substantial limitation on the scope of the implied right of action under section $10(\mathrm{~b})$ and rule $10 \mathrm{~b}-5$, stressing that the implied remedy must not nullify the purpose and effectiveness of the express hability provisions. ${ }^{44}$ The Court held that a section $10(\mathrm{~b})$ action would reach only willful and knowing acts and not negligent misstatements or omissions. ${ }^{45}$ As in Blue Chip Stamps, the Court based its decision partly on its interpretation of Congress's intent in passing section 10(b). ${ }^{46}$ Nevertheless, a second important basis for the Court's holding in Hochfelder

39. $42 \mathrm{I}$ U.S. at 733.

40. Securities Act of 1933, section 11, 15 U.S.C. \& 77k (1976) (civil liability for false registration statements); section 12, 15 U.S.C. \& 77/ (1976) (civil liability arising in connection with prospectuses and communications). Securities Exchange Act of 1934, section 9, 15 U.S.C. \&78i (1976) (civil liability for inanipulation of security prices); section 18, 15 U.S.C. \& 78r (1976) (civil liability for false or misleading statenents in documents filed with the SEC).

41. 421 U.S. at 736.

42. The Court also rested its decision on policy considerations. See note 51 infra and accoinpanying text.

43. 425 U.S. 185 (1976).

44. In Hochfelder, an investor who had utilized the services of a brokerage firm sought damages from Ernst \& Ernst, the firm's public accountant, in a civil action for negligence brought under section $10(\mathrm{~b})$ and rule $10 \mathrm{~b}-5$. The plaintiff alleged that Ernst \& Ernst had failed to discover a fraudulent securities scheme perpetrated by the brokerage firm's president.

45. 425 U.S. at 214. The Court reversed the Court of Appeals for the Seventh Circuit, which had held that a breach of a duty of inquiry and disclosure would result in liability for damages for aiding a third party's violation of rule $10 \mathrm{~b}-5$ if the fraud would have been discovered or prevented but for the breach. Hochfelder v. Ernst \& Ernst, 503 F.2d 1100 (7th Cir. 1974). The other courts of appeals were divided on the issue. The Second, Third, Fourth, Fifth, Sixth, and Tenth Circuits required more than mere negligence, while the Seventh and the Ninth Circuits reached the contrary conclusion. See Cox 569-70.

46. The Court found that the use of the words "manipulative or deceptive devices or contrivances" indicated Congress's intent to proscribe knowing or intentional misconduct "designed to deceive or defraud investors." 425 U.S. at 199. The Court also concluded that the legislative history of section $10(\mathrm{~b})$ contamed no indications of congressional intent to proscribe conduct not involving scienter. Id. at 202. See also Aaron v. SEC, 100 S. Ct. 1945 (1980). 
was its belief that the scheme of the federal securities laws would be seriously disrupted if courts interpreted section $10(\mathrm{~b})$ to reach negligent acts. Plaintiffs suing under provisions expressly imposing liability for negligence inust satisfy certain procedural limitations. Simce an implied action under section 10(b) imposed none of these limitations, ${ }^{47}$ the Court concluded that the use of a neghigence standard in section 10 (b) actions would effectively negate the procedural restrictions present in the other provisions. ${ }^{48}$

The Court has used various processes of reasoning in limiting the scope of implied causes of action. In virtually all of its decisions, ${ }^{49}$ it has engaged in a close analysis of the statutory language and the legis-

47. Sections 11, 15 U.S.C. $\$ 77 \mathrm{k}$ (1976) and 12(2), 15 U.S.C. $\$ 77 /(2)$ (1976) of the Securities Act of 1933 expressly impose liability for negligence in the sale or offering of securities. Several procedural restrictions in the express liability sections are generally not duplicated in the section 10(b) implied private action. For exainple, the statute of limitations for actions brought under sections 11 and 12 requires suit to be brought within one year of discovery of the wrong and under no circuinstances more than three years after the shares were offered to the public or after the sale. 15 U.S.C. $\& 77 \mathrm{~m}$ (1976). In actions brought under section 10(b) for the conduct prohibited by sections 11 and 12, the courts of appeals have followed analogous state law, in accordance with Holmberg v. Armbrecht, 327 U.S. 392 (1946). This has usually resulted in a longer statute of limitations. See A. Bromberg $\S 2.5(1)$. Sections 11 and 12(2) also permit courts to require that plaintiffs suing under those sections post security for the defendant's expenses. This procedural limitation has not been imposed on plaintiffs suing under the section $10(b)$ inplied private action. A. BROMBERG $\S 2.5(2)$. Finally, there are shight advantages in the venue provision applicable to section 10(b) plaintiffs. Venue under section 22 of the Securities Act of 1933, which apphies to sections 11 and 12(2), lies where the defendant is found, resides or transacts business or where the offer or sale took place. 15 U.S.C. $\& 77 v($ a) (1976). Section 27 of the Securities Exchange Act of 1934,15 U.S.C. $\$ 78 a a(1976)$, also perinits venue im any district in which any act or transaction constituting a violation occurred. Thus, if the misrepresentation occurs outside of the state where the sale occurred, a section $10(\mathrm{~b})$ action could be maintained either in the state of the misrepresentation or in the state where the sale oceurred. Actions under sections 11 or 12 , on the other hand, would only be heard in the state of sale. See Cox 584 .

48. The Court stated: "Such extension of [section 10 to include negligent conduct] would allow causes of action covered by $\$ \S 11,12(2)$ and 15 [the provisions imposing liability for negligence] to be brought instead under $\$ 10(b)$ and thereby nullify the effectiveness of the carefully drawn procedural restrictions on these express actions." 425 U.S. at 210 . The procedural requirements of section $10(\mathrm{~b})$ as fashioned by the lower courts are, in many instances, considerably more relaxed than are those restrictions imcluded in the express liability provisions. See notes 84-89 infra and accompanying text.

49. Other Supreme Court decisions since 1975 have placed restrictions on the section 10(b) implied action and on other private rights of action that previously had been inplied. E.g., Sunta Fe v. Green, 430 U.S. 462 (1977) (no cause of action inplied under section 10(b) and rule 10b-5 for breach of corporate fiduciary duty not involving inanipulation or deception); TSC Indus. v. Northway, Inc., 426 U.S. 438 (1976) (requirement of materiality in rule 14a-9 imphied action defined as requiring substantial likelihood that reasonable shareholder would consider inisrepresentation or omission important in deciding low to vote).

In Piper v. Chris-Craft Indus., 430 U.S. 1 (1977), the Court declined to find a private cause of action under section 14(e) of the Securities Exchange Act of 1934, 15 U.S.C. \& 78n(e) (1976), for a defeated tender offeror, although it reserved the question whether section 14(e) might permit an implied action for corporate shareholders. 430 U.S. at 45. 
lative history. ${ }^{50}$ The Court has also used policy considerations ${ }^{51}$ and the Cort v. Ash tests. ${ }^{52}$ Finally, in Blue Chip Stamps and Hochfelder, the Court expressed concern about the impact that expansion of an implied right of action might have upon the effectiveness of the express rights of action included within the statutory scheme. Thus, the concern for statutory disruption evident in the Court's decision in Touche Ross \& Co. v. Redington, in which the Court declined to find any implied private right of action, ${ }^{53}$ is also present in decisions determining the scope of existing imphed rights of action.

\section{B. The Concern for Harmonization of Private Rights of Action Within the Statutory Scheme.}

As illustrated by the Supreine Court's decisions in Redington, Blue Chip Stamps, and Hochfelder, ${ }^{54}$ a question concerning the likely impact of finding an imphed cause of action upon the statutory scheme may arise during the initial decision to imply a private right of action and during subsequent inquiries about the scope of a previously recognized implied private action. Express hability provisions are often carefully drawn to cover specific statutory violations and to impose specific substantive and procedural restrictions on would-be plaintiffs. For example, section 18(a) of the Securities Exchange Act of 1934, ${ }^{55}$ which prohibits the filing of materially misleading reports with the Securities and Exchange Commission, expressly permits private suits. The sec-

50. The Court thus has used essentially the same approach in defining the contours of the implied actions as it has used in determining whether to imply a new right of action. See generally Note, The Supreme Court's Trimming of the Section 10(b) Tree: The Cultivation of a New Securities Law Perspective, 3 J. CoRP. L. 112, 132-33 (1977).

51. E.g., Blue Chip Stamps v. Manor Drug Stores, 421 U.S. 723, 737-39 (1975) (conclusion that section $10(\mathrm{~b})$ and rule $10 \mathrm{~b}-5$ implied actions are limited to purchasers and sellers of securities is reinforced by pohcy agamst vexatious litigation which might result from an expanded class of plaintiffs). See also International Bhd. of Teamsters v. Damel, 439 U.S. 551 (1979); United Hous. Foundation, Inc. v. Forman, 421 U.S. 837, 855-57 (1975) (exclusion of cooperative housing shares from definition of "securities" under securities laws based, in part, on pohicy considerations against including speculative and insubstantial transactions within the securities acts).

52. In Piper v. Chris-Craft Indus., 430 U.S. 1, 37 (1977), the Court rehed on a Cort v. Ash analysis to support its finding that defeated tender offerors have no standing to sue under section 14(e) of the Securities Exchange Act of 1934, 15 U.S.C. $\$ 78 n(e)$ (1976). The Court initially reached its conclusion through an examination of the statutory language and legislative history. In Santa Fe v. Green, 430 U.S. 462, 477-79 (1977), the Court concluded that a section 10(b) plaintiff must show that the alleged breach of corporate fiduciary duty is manipulative. The Court supported this conclusion by focusing on the state concern factor of tle Cort test. Tlus, the Court found that it was appropriate to relegate to state law what was essentially a claim of corporate mismanageınent.

53. See notes 28-34 supra and accompanying text.

54. See text accoinpanying notes $31-34$ \& 40-48 supra.

55. 15 U.S.C. $\$ 78 \mathrm{r}(\mathrm{a})(1976)$. 
tion imposes a relatively short statute of limitations ${ }^{56}$ and grants the district court discretion to require either party to pay the costs of the suit, including reasonable attorney's fees..$^{57}$ Generally, courts have interpreted section 18(a) to require that plaintiffs asserting a cause of action under that provision prove actual rather than constructive reliance on the misstatements. ${ }^{58}$ Moreover, section 18(a) expressly permits the issuer of stock to raise a defense of good faith and lack of knowledge that the statement was false or misleading. ${ }^{59}$

Nevertheless, specific requirements of the express liability provisions are essentially nullified if plaintiffs may sue for the saine statutory violation under an implied right of action that is not subject to the barriers contamed im the express provisions. ${ }^{60}$ Such nullification causes serious disruption of a carefully designed regulatory scheme since plaintiffs will enjoy procedural or substantive advantages not intended by Congress. Because courts have often found implied private rights of action in statutes of potentially broad application, the possibility of overlap between implied rights of action and generally narrower express liability provisions is always present. ${ }^{61}$ Section $10(\mathrm{~b})$, for example, is a general proscription against the use of any mampulative device or contrivance in connection with the purchase or sale of any security. Misleading reports filed with the Securities and Exchange Commission have been lield to constitute inanipulative devices within the aunbit of section 10(b), thus creating an overlap between the implied right of action under section $10(\mathrm{~b})$ and the express right of action under section 18(a). ${ }^{62}$ Section 10(b) traditionally has been held to impose less strimgent substantive ${ }^{63}$ and procedural requirements ${ }^{64}$ than section 18(a).

56. The section 18(a) express right of action is subject to the statute of limitations set forth in section 18(c), 15 U.S.C. \& 78r(c) (1976). That section limits actions to within one year after discovery of the facts constituting the cause of action and witlin three years after the cause of action accrued.

57. 15 U.S.C. \& $78 \mathrm{r}(\mathrm{a})$ (1976).

58. See, e.g., Heit v. Weitzen, 402 F.2d 909 (2d Cir. 1968), cert. denied, 395 U.S. 903 (1969). See also A. JACOBS, supra note $14, \S 3.02$ [h].

59. 15 U.S.C. $\$ 78 \mathrm{r}(\mathrm{a})$ (1976).

60. See notes $85-89$ infra and accompanying text.

61. Each of the express liability provisions of the securities acts, for example, is drawn much more narrowly than section 10(b)'s general proscription agamst manipulation or deception in connection with the purchase or sale of any security. See note 14 supra.

62. See, e.g., Ross v. A.H. Robins Co., 607 F.2d 545 (2d Cir. 1979), cert. denied, 100 S. Ct. 2175 (1980); Wachovia Bank \& Trust Co. v. National Student Marketing Corp., 461 F. Supp. 999 (D.D.C. 1978); Gross v. Diversified Mortgage Investors, 431 F. Supp. 1080 (S.D.N.Y. 1977); Seiden v. Nicholson, 69 F.R.D. 681 (N.D. Ill. 1976).

63. The section 10(b) imphed action has, for example, been held not to require that plaintiffs show reliance. Affiliated Ute Citizeus v. United States, 406 U.S. 128 (1972). Prior to the Supreme Court's decision in Ernst \& Ernst v. Hochfelder, 425 U.S. 185 (1976), some courts also permitted 
Hence, a plaintiff who alleges misrepresentations in a document filed with the Commission can avoid the more onerous requirements of the express hability provision inerely by suing under section $10(\mathrm{~b})$.

Less serious disruption of the regulatory scheme may result, however, if plaintiffs have an implied right of action that imposes different restrictions from those included in the express provision if those different restrictions are significant. In this situation there is little negative impact on the effectiveness of restrictions included in the express provisions, especially when the implied action's requirements closely resemble the express restriction, or when they tend to effectuate the same legislative policies. ${ }^{65}$

Prior to the mid-1970s, implied private rights of action were often found and subsequently expanded almost without limitation. ${ }^{66}$ When a court adopted a liberal attitude toward implied riglits of action, it had little concern for the potential impact that the imcreased availability of implied private actions might have upon the effectiveness of express liability provisions. ${ }^{67}$ Consequently, plaintiffs were often able to bring suit under an implied right of action and avoid the substantive or procedural requireinents that Congress had included in the express liabil-

plaintiffs to sue under section 10 (b) without proof of scienter. See note 45 supra and accompanying text.

64. Scction 10(b), 15 U.S.C. $\S 78 j$ (b) (1976), and rule 10b-5, 17 C.F.R. $\$ 240.10 b-5$ (1977), contain no provision setting a statute of limitations or determining apportionment of attorney's fees and costs. Courts have imposed state statutes of limitations on actions under section 10(b) and rule 10b-5. A. BROMBERg § 2.5(1). See note 85 infra and accompanying text. The district court's power to award attorney's fees, on the other hand, has been sharply circumscribed by Suprene Court decisions. See Alyeska Pipeline Serv. Co. v. Wilderness Soc'y, 421 U.S. 240 (1975) (showing of "bad faith" required for award of attorney's fees to successful defendant in absence of statutory authorization); F.D. Rich Co. v. United States ex rel. Industrial Lumber Co., 417 U.S. 116, 129 (1974), cited in Ernst \& Ernst v. Hochfelder, 425 U.S. 185, 211 n.30 (1975).

65. See text accoinpanying notes $147-68$ infra.

66. The best example of this growth is the implied private action under section 10(b) and rule 10b-5, which has been referred to as "a judicial oak which has grown from little more than a legislative acorn." Blue Chip Stainps v. Manor Drug Stores, 421 U.S. 723, 737 (1975). Thus, the implied action has been used to proscribe a wide variety of frauds in connection with securities transactions. Similarly, a number of courts implied a right of action under section 17(a) of the Securities Act of 1933 as a parallel to the section 10(b) private action. See, e.g., Newman v. Prior, 518 F.2d 97 (4th Cir. 1975); Lanza v. Drexel \& Co., 479 F.2d 1277, 1280 n.2 (2d Cir. 1973). One coininentator has criticized the use of the section 17(a) implied right of action as a mere "tagalong" section to 10(b). Hazen, A Look Beyond the Pruning of Rule 10b-5: Implied Remedies and Section I7(a) of the Securities Act of 1933, 64 VA. L. REv. 641 (1978). Traditionally, courts have also taken a broad approach to implied remedies in connection with civil rights legislation such as 42 U.S.C. § 1982 (1976). See, e.g., Sullivan v. Little Hunting Park, Inc., 396 U.S. 229 (1969) (damage remedy for lousing discrimination permitted under section 1982); Jones v. Alfred H. Mayer Co., 392 U.S. 409 (1968) (injunctive relief for lousing discrimination granted under section 1982); Hurd v. Hodge, 334 U.S. 24, 30-36 (1948) (implied action under section 1982 found to prevent enforceinent of racially restrictive covenants by the courts of the District of Columbia).

67. See note 82 infra and accoinpanying text. 
ity provisions. While some lower courts attempted to limit this bypassing of statutory requirements, many others viewed the implied and express private actions as cumulative and permitted the practice. ${ }^{68}$

During this period the Supreme Court did not rule on the proper relationship between express and implied rights of action. The Court's liberal attitude toward implied rights of action seemed, however, to sanction atteinpts to circumvent restrictions imcluded in the express liability provisions as long as the implied private action effectuated the legislative purpose. ${ }^{9}$ Furthermore, in SEC v. National Securities Inc. ${ }^{70}$ the Court stated in dictum that some overlap between express and implied rights of action would be permissible even if the implied action included more relaxed substantive or procedural requirements. ${ }^{71}$

Under the more restrictive approach used in the Supreme Court's recent cases, ${ }^{72}$ the existence of express liability provisions im an act has a significant impact both on the decision to recognize an implied right of action and on the determination of the scope of the private actions already implied. Thus, in Blue Chip Stamps, the Court limited the scope of the section 10(b) and rule 10b-5 right of action to purchasers and sellers of securities partly because the express liability provisions of the securities acts were similarly limited. ${ }^{73}$ In Hochfelder, the Court refused to extend the section 10(b) implied action to neghigent conduct, noting that the express provisions of the securities acts proscribing neghigent misconduct contam strict procedural requirements that could be negated if section 10(b) and rule $10 \mathrm{~b}-5$ gave rise to an implied action for negligence. ${ }^{74}$ Fimally, the Court indicated in Redington that it would not infer a private right of action from a statute if that inference would allow a plaimtiff to avoid the substantive requirenents of an express liability provision in the same act. ${ }^{75}$

68. See notes $81-83$ infra and accompanying text.

69. The Supreme Court stressed that remedial legislation should be construed broadly to effectuate its purposes. See Tcherepnin v. Knight, 389 U.S. 332, 336 (1967); J.I. Case Co. v. Borak, 377 U.S. 426, 432 (1964). Some lower courts imterpreted this liberal attitude as permitting avoidance of the restrictions imcluded in the express hability provisions. See, e.g., Jordan Bldg. Corp. v. Doyle, O'Connor \& Co., 40I F.2d 47, 49-50 (7th Cir. 1968).

70. 393 U.S. 453 (1969). Diseussing the interrelationship of sections IO(b) and I4 of the Securities Exchange Act of 1934, the Court noted in National Securities that the "fact that there may well become overlap [between the sections] is neither unusual nor unfortunate." 393 U.S. at 468. Courts have interpreted this language as supporting overlap between implied and express rights of action. See, e.g., Wachovia Bank \& Trust v. National Student Marketing, 46I F. Supp. 999, 1006 n. 15 (D.D.C. 1978).

71. 393 U.S. at 468.

72. See text accompanying notes $16-53$ supra.

73. See notes $40-42$ supra and accompanying text.

74. See notes $43-48$ supra and accompanying text.

75. See notes 31-34 supra and accompanying text. 
While the Supreme Court clearly has adopted a policy of harmonizing express and implied private rights of action, the Court has not explicitly indicated the extent to which implied actions will otherwise be allowed to disrupt the statutory scheme. The Court's decisions could be interpreted as mandating a policy of nondisruption. ${ }^{76}$ On the other hand, a policy of harmonizing the provisions in a federal statute does not necessarily require that all disruption be avoided. ${ }^{77}$ Given the paucity of elaboration in the Court's decisions, the lower courts have been left to formulate their own approaches to harmonization consistent witl the Court's mandate that the effectiveness of the express liability provisions not be nullified.

\section{Alternative Approaches for Harmonizing Private RIGHTS OF ACTION WITH THE EXISTING STATUTORY SCHEME}

The lower courts traditionally have devised their own approaches to determine the proper interrelationship of express and implied rights of action. Four different approaches emerged from the lower court decisions that preceded the Supreme Court's adoption of a restrictive attitude toward implied remedies. ${ }^{78}$ An examination of these approaches in light of the Court's present restrictive policy indicates that at least two can be reconciled with the Court's recent decisions. ${ }^{79}$ The better approach recognizes that limited disruption of the statutory scheme is not necessarily imconsistent with a policy of harmonization. Courts should permit limited overlap between implied and express rights of action as long as the express liability provisions are not negated by allowing alternate rights of action. ${ }^{80}$

\section{A. Lower Court Approaches to Interrelating Actions in Light of the New Law of Implication.}

1. Free Overlap. The most liberal approach developed by lower courts prior to 1975 permitted free overlap between imphed and express rights of action. Under this approach, implied and express pri-

76. See text accompanying notes 123-25 infra.

77. Cox 585. The author suggests that equating harmony with a prohihition against all conflict between express and implied private actions fails to recognize that soine overlapping between the express and the implied causes of action may be consistent with the goals of the legislation. Id. 602 .

78. While the lower court decisions often vary in their precise rationales, their approaches can be divided quite readily into four general categories. See notes 81-151 infra and accompanying text.

79. See text accompanying notes 123-25 \& 159-61 infra.

80. See text accompanying notes $147-48$ infra. 
vate actions were "cumulative and not mutually exclusive." 81 Implied private rights of action thus were found and extended without regard for the potential impact upon the effectiveness of express hability provisions. ${ }^{82}$ The usual justification for permitting free overlap was that remedial legislation should be construed broadly to effectuate its purposes. ${ }^{83}$ When a court concluded that the legislative purpose was to afford adequate remedies to imjured plaintiffs, it was considered counterproductive to duplicate those elements of the express hability provisions that might deny an injured party rehief.

The free overlap approach could be of tremendous advantage to plaintiffs. ${ }^{84}$ For example, in the case of section $10(\mathrm{~b})$ and rule $10 \mathrm{~b}-5$, a plaintiff proceeding under the imphed right of action could avoid the following restrictions that exist under the express hability provisions: (1) the generally shorter statute of limitations; ${ }^{85}$ (2) the requirements of postimg security for expenses; 86 (3) the more stringent privity requirements; ${ }^{87}$ and (4) the more difficult requirements for proving market manipulation through false reports filed with the Securities and Exchange Commission. ${ }^{88}$ The relaxed requirements of section $10(\mathrm{~b})$ and

81. Jordan Bldg. Corp. v. Doyle, O'Connor \& Co., 401 F.2d 47, 51 (7th Cir. 1968).

82. Schaeffer v. First Nat'1 Bank, 509 F.2d 1287 (7th Cir. 1975), cert. denied, 425 U.S. 943 (1976); Seiden v. Nicholson, 69 F.R.D. 681 (N.D. Ill. 1976); Unicorn Field, Inc. v. Cannon Group, Inc., 60 F.R.D. 217, 224 (S.D.N.Y. 1973).

Considerable overlap between implied and express rights of action occurred during the period of expansion of implied rights of action. See, e.g., Stewart v. Travelers Corp., 503 F.2d 108 (9th Cir. 1974) (implication depends on whether statute's protection would be enhanced by allowing overlapping private civil relief; cause of action inferred from section 302a of Consumer Credit Protection Act, 15 U.S.C. $\$ \$ 1601-1691$ (1976)); Jordan Bldg. Corp. v. Doyle, O'Connor \& Co., 401 F.2d 47 (7th Cir. 1968) (plaintiff allowed to sue under rule 10b-5 although defendant's alleged conduct fell squarely within section 12 of the Securities Act of 1933, 15 U.S.C. $\$ 771$ (1976), and section 15 of the Securities Exchange Act of 1934, I5 U.S.C. $\$ 780$ (1976)).

83. See Tcherepnim v. Knight, 389 U.S. 332, 336 (1967); J.I. Case Co. v. Borak, 377 U.S. 426, 432 (1964); Jordan Bldg. Corp. v. Doyle, O’Connor \& Co., 401 F.2d 47, $49-50$ (7th Cir. 1968). See note 69 supra and accompanying text.

84. See text acconipanying note 68 supra.

85. State statutes of limitation govern a rule $10 \mathrm{~b}-5$ implied action, see Charney v. Thomas, 372 F.2d 97, 99-100 (7th Cir. 1967); Fischınan v. Raytheon Mfg. Co., 188 F.2d 783 (2d Cir. 1951), and are generally longer than the statutes of limitations expressly provided in the securities acts. A. BROMBERG $\S 2.5(1)$.

86. Under the express liability provisions the district courts nray assess court costs and attorney's fees agaimst a losing plaintiff. A. BromBERG § 2.5(2).

87. The privity between plaintiff and defendant neccssary to maintain an action is fairly relaxed im the express hability provisions. For example, sections 12(2) and 15 of the Securities Act of 1933 permit a buyer to recover from a seller (generously construed) or from anyone in control of the seller. Traditionally, the privity requirement in a rule $10 \mathrm{~b}-5$ implied action was even inore relaxed, requiring only that the misconduct be " $\mathrm{m}$ connection with" the sale or purchase of a seeurity. A. BROMBERG $\S 2.5(3)$.

88. The proof requirements of a section 18(a) express right of action, for example, are much more difficult to satisfy than those under rule $10 \mathrm{~b}-5$. Under section 18(a), a plaintiff must prove 
rule 10b-5 resulted in a proliferation of lawsuits under the implied right of action, while the express liability provisions of the Securities Exchange Act fell into relative disuse. ${ }^{89}$

Despite the Supreine Court's recent restrictive position toward implied rights of action, some lower court decisions continue to treat implied and express remedies as cumulative. Several recent decisions have limited the Blue Chip Stamps and Hochfelder analysis of the proper scope of implied private actions to the specific statutory provisions involved in those cases. ${ }^{90}$ Thus, neithcr case is viewed as implicitly overruling decisions adhering to the free overlap approach.

This interpretation is contrary to the Court's statement in Hochfelder that implied rights of action must not be extended so as to "nullify the effectiveness of the carefully drawn procedural restrictions on ... express actions."91 Although the language in the Supreme Court's earlier decision in $S E C v$. National Securities $I n c^{92}$ indicates that overlap between remedies might be permissible, ${ }^{93}$ Hochfelder, Blue Chip Stamps, and Redington modify that language and require that the contours of implied reinedies be determined, in part, by cross reference to the express liability provisions. ${ }^{94}$ The Supreme Court's use of the expressio unius rule to deny implied rights of action also seems to require reference to express provisions. ${ }^{95}$ While it is unclear whether the Court will apply the inaxim in determining the interrelationship of pri-

actual reliance on misleading documents filed with the SEC. See Heit v. Weitzen, 402 F.2d 909, 916 (2d Cir. 1968), cert. denied, 395 U.S. 903 (1969). Hence, only "the diligent few who peruse filed corporate reports" can bring an action under the section. Blue Chip Stamps v. Manor Drug Stores, 421 U.S. 723, 745 (1975). See A. Bromberg \& 2.5(4); III L. LosS, Securities RegulaTION 1751-54 (2d ed. 1961). Under the rule 10b-5 imphed action, in contrast, plaintiffs have, in certain contexts, been relieved of the burden of proving rehance. See Affiliated Ute Citizens v. United States, 406 U.S. 128 (1972) (no requirement of proving rehance in rule 10b-5 actions involving nondisclosure or a material misrepresentation). See generally Note, Reliance Requirement in Private Actions under SEC Rule 10b-5, 88 HARv. L. REv. 584 (1975) (lower courts are divided about whether a presumption of rehance exists in all private actions under rule 10b-5). See note 63 supra.

89. See A. JACOBS, supra note $14, \S 302[\mathrm{j}]$.

90. Wachovia Bank \& Trust v. National Student Marketing, 461 F. Supp. 999, 1006 n.15 (D.D.C. 1978); accord, Wolgin v. Magic Marker Corp., 82 F.R.D. 168, 180 (E.D. Pa. 1979); Helfand v. Cenco, Inc., 80 F.R.D. 1, 9 (N.D. Ill. 1977); Seiden v. Nicholson, 69 F.R.D. 681,684 (N.D. III. 1976).

91. 425 U.S. at 102.

92. 393 U.S. 453 (1969).

93. See note 70 supra and accompanying text.

94. See text accompanying notes 73-75 supra.

95. See, e.g., Transamerica Mortgage Advisors, Inc. v. Lewis, 444 U.S. 11, 18-19 (1979); Touche Ross \& Co. v. Redington, 442 U.S. 560 (1979); National R.R. Passengers Corp. v. National Ass'n of R.R. Passengers, 414 U.S. 453, 458 (1974). See notes 18 \& 26 supra and accoinpanying text. 
vate rights of action, its use by the Court in deciding whether to imply rights of action at all inibtates against free overlap. The continued validity of the free overlap approach thus is dubious in light of the Supreme Court's concern for the statutory scheine of express and implied causes of action.

2. In Pari Materia. A second group of decisions attempted to harmonize express and imphed reinedies by construing thein in pari materia. ${ }^{96}$ Under this approach, the implied right of action was construed to effectuate the legislative policy embodied in restrictions contained in any express hability provisions covering the saine statutory violation. ${ }^{97}$ A plaintiff injured by conduct proscribed by the express provision inight be perinitted to sue under an implied right of action, but he would be required to satisfy whatever substantive and procedural requireinents the court deeined necessary to effectuate the legislative pohcy advanced by the express provision. ${ }^{98}$ In Rosenberg $v$. Globe Aircraft Corp. ${ }^{99}$ for example, a district court imposed the venue requirements of sections 11 and 12 of the Securities Act of $1933^{100}$ on an implied action under section 10(b) based on a misleading prospectus. Suits based on that particular violation of the Securities Act are expressly permitted in sections 11 and 12 of the Act. The court found that the express procedural requireinents included in sections 11 and 12 evidenced a congressional policy of imposing significant restrictions on actions for particular types of statutory violations. The court reasoned that an implied action covering conduct also proscribed by sections 11 and 12 inust imclude the procedural restrictions which Congress chose to imclude in those express liability provisions:

[Congress] in Secs. 11 and 12, 15 U.S.C.A. $\$ \S 77 \mathrm{k}$ and $77 l$, has prescribed what amounts to a code of procedure . . . . Looking at the implied and express private actions] as one statute it is simply not possible that Congress, having prescribed in elaborate detail procedural requirements which must be fulfilled in order to enforce civil liability attaching to a carefully defined type of violation, would have casually nullified them all in a later section. ${ }^{101}$

Construing statutory provisions in pari materia avoids possible disruptions of the statutory scheme and revitalizes the express hability

96. Relating to the same subject matter, see United States v. Stewart, 311 U.S. 60,64 (1940);

2A C. SANDs \& A. Sutherland, Statutory Construction $\$ 51.03$, at 298-99 (4th ed. 1973).

97. 2 A. Sutherland, Statutory Construction $§ 5201$, at 530 (1943).

98. Id. at 530-31.

99. 80 F. Supp. 123 (E.D. Pa. 1948).

100. 15 U.S.C. $\$ \$ 77 \mathrm{k}, 77 /(1976)$.

101. 80 F. Supp. at 124. 
provisions. ${ }^{102}$ In Piper v. Chris-Craft Industries, ${ }^{103}$ the Supreme Court indicated that the in pari materia rule may be useful im identifying the elements of implied rights of action.104 Piper involved rule 10b-6, which prohibits market tampering by issuers whose stock is in the process of distribution. Under the rule, issuers may not buy the stock or the right to purchase the stock until the distribution has been completed. The Court held that implied actions under rule $10 \mathrm{~b}-6$ require that the alleged violations of rule 10b- 6 actually have affected the price paid for stock during the distribution. The Court supported its holding by comparing rule 10b-6 to section 9 of the Securities Exchange Act, ${ }^{105}$ which creates an express remedy in favor of "any person who shall purchase or sell any security at a price which was affected by [an unlawful market activity]." 106 Noting the close relationship between rule 10b-6 and section 9, the Court reasoned that rule 10b-6 also requires that the manipulative activity have influenced the amount an investor paid for the stock. ${ }^{107}$ Likewise, in Ernst \& Ernst v. Hochfelder, the Supreme Court suggested that the implied private action in section 10(b) is to be construed in pari materia with sections 9 and 18 of the Securities Exchange Act. ${ }^{108}$ In concluding that section 10(b) only covers acts imvolving a lack of good faith, the Hochfelder Court relied on the legislative history of sections 9 and $18 .{ }^{109}$

Despite the Court's statements in Piper and Hochfelder that the elements of implied rights of action may be identified by referring to express liability provisions, the Court has never imsisted that express and implied private actions be interpreted in pari materia so as to limit

102. Construing actions in pari materia is much more restrictive than the free overlap approach and may refiect judicial concern for preventing disruption of the statutory scheme. See Rosenberg v. Globe Aircraft Corp., 80 F. Supp. 123 (E.D. Pa. 1948). But see Globus v. Law Research Serv., lnc., 418 F.2d 1276, 1286 (2d Cir. 1969) (section 17(a) action should follow rule 10b-5 actions because of identical language in each enactment; sections construed in pari materia), cert. denied, 397 U.S. 913 (1970).

103. 430 U.S. 1 (1977).

104. Id. at 26. Piper involved an unsuccessful tender offer by Chris-Craft Industries in a contest against Bangor Punta Corporation and the existing management of Piper Aircraft Corporation for control of Piper. Chris-Craft and Bangor Punta each had acquired substantial blocks of Piper shares before Bangor Punta ultimately secured control. Id. at 4-10.

105. 15 U.S.C. \& $78 \mathrm{i}$ (1976).

106. Id. (emphasis added).

107. 430 U.S. at $45-46$.

108. 15 U.S.C. $\$ \$ 78 \mathrm{i}, 78 \mathrm{r}$ (1976). See 425 U.S. at 209 n.28.

109. 425 U.S. at 207-11. The Court thus found that the legislative history of section 18(a) suggests that "something more than negligence on the part of the defendant is required for recovery" under the anti-fraud provisions of the Securities Exchange Act. Id. at 211 n.31. Imphicit in this construction is the suggestion that section $10(\mathrm{~b})$ is to be interpreted in pari materia with sections 9 and 18. For the Exchange Act, the elements of section 10(b) would accordingly be determined by reference to the elements of the express hability provisions. See Cox 596. 
the scope of implied actions by the substantive and procedural requirements of the express liability provisions. The Court thus has not foreclosed the use of implied causes of action to avoid the restrictions of the express actions. ${ }^{110}$ Furthermore, there are a number of problems inherent in the in pari materia approach that militate against its use. First, the in pari materia approach may misapprehend congressional intent by assuming that no statutory disruption is tolerable. The existence within the securities acts of overlapping express hability provisions with different substantive requirenents suggests that some statutory disruption surely is acceptable to Congress. ${ }^{111}$ Second, construmg rights of action in pari materia can present problems in selectimg the referent express provision when more than one provision proscribes the same conduct. As one commentator has suggested, the mquiry into which express provision should govern "will turn on the strength of the analogy between the challenged conduct and that proscribed in an express liability section, over which differences of opinion will be most pronounced." 112 Finally, interpreting rights of action in pari materia may create artificial results. ${ }^{113}$ Plaintiffs suing under an imphed action for particular conduct proscribed by an express liability section may be required to meet the generally more strenuous requireinents of the express provision. If the event that triggers the application of the express liability section is not present, however, the plaintiff would be permitted to proceed under the more relaxed requirenents of the implied right of action, even though the conduct is essentially the same as that proscribed by the express provision. For example, a plaintiff who sued under section 10(b) after relying on a misleading report filed with the Securities and Exchange Commission would be bound by the restrictions included in the relevant express provision, section 18(a), whereas a plaintiff who relied on a misleading prospectus and who bought on the open market would be subject only to the inore relaxed requirements that have developed under section 10(b). The line drawn between these two classes of plaintiffs under the in pari materia approach may often have little to do with the objectives of the statute. ${ }^{114}$

3. Presumption of Exclusivity of an Express Right of Action. Another restrictive approach taken by lower courts prior to 1975 was to raise a presumption of exclusivity of an express hability provision.

110. See Cox 597.

111. See notes 138-39 infra and accompanying text.

112. Cox 598.

113. Id. 598-99.

114. Id. 599. 
Under this approach, the existence of an express right of action was virtually conclusive evidence of a deliberate legislative intent to exclude imphed rights of action for the challenged conduct.115 Exclusivity thus relied upon the expressio unius inaxim of statutory construction. ${ }^{116}$ Implied rights of action under this approach were viewed as catch-all provisions, applying only to conduct not proscribed by the express liability provisions, unless there was convincing evidence that Congress intended overlapping private actions. ${ }^{117}$ Convincing evidence of legislative intent to permit an implied action for particular conduct is unlikely to exist, however. If Congress actually had considered the matter of private actions to the extent that it appeared in the language or history of the statute, the statute itself probably would contaim a declaration that a private action does or does not exist or may or may not overlap with other rights of action. ${ }^{118}$ Therefore, the presumption raised by this approach is likely to be virtually irrebuttable. Plaintiffs alleging conduct proscribed by an express hability provision would, in most instances, be limited to suing under that section, subject to the section's substantive and procedural requirements.

Although the exclusivity approach significantly restricts the scope of implied causes of action, the results under it do not greatly differ from those obtained by construing implied and express rights of action in pari materia. ${ }^{119}$ When the challenged conduct falls within the ambit of an express liability section, plaintiffs under either approach are required to overcome barriers specifically set forth by Congress before they can maintain an action. The exclusivity approach does, however, avoid the necessity of forcing a court to choose between referent provisions if more than one exists. ${ }^{120}$ Furthermore, the approach takes into account the possibility of legislative intent to allow disruption, ${ }^{121}$ al-

115. See In re Penn Cent., 347 F. Supp. 1327 (E.D. Pa. 1972) (no implied right of action under reporting requirements of section 13(a) of Securities Exchange Act; section 18(a) exclusive remedy), aff'd, In re Penn Cent. Sec. Litigation, 494 F.2d 528 (3d Cir. 1974); accord, du Pont v. Wyly, 61 F.R.D. 615 (D. Del. 1973). See also Network Project v. Corporation for Pub. Broadcasting, 561 F.2d 963, 966-67 (D.C. Cir. 1977) (private right of action would not harmonize with congressional intent as evidenced in statutory scheme of Public Broadcasting Act of 1967, 47 U.S.C. $\S 396(\mathrm{a})$, (g) (Supp. II 1978)), cert. denied, 434 U.S. 1068 (1978); Ferland v. Orange Groves of Fla., Inc., 377 F. Supp. 690, 706 (M.D. Fla. 1974) (statutory scheme of Securities Act of 1933 evidence that no implied action intended under section 17(a) of 1933 Act).

116. See note 18 supra and accompanying text.

117. See In re Penn. Cent. Sec. Litigation, 494 F.2d 528, 540-41 (3d Cir. 1974); Traylor v. Safeway Stores, Inc., 402 F. Supp. 871 (N.D. Cal. 1975).

118. Comment, Private Rights of Action Under Amtrak and Ash: Some Implications for Implication, 123 U. PA. L. REv. 1392, 1412 (1975).

119. See notes 97 \& 98 supra and accompanying text.

120. See text accompanying note 112 supra.

121. See text accoinpanying note III supra. 
though requiring convincing proof of such legislative intent to permit overlap makes this aspect of the exclusivity approach of little practical assistance to plaimtiffs. ${ }^{122}$

The Supreine Court's recent decisions provide some support for the exclusivity approach. The Hochfelder Court's imstruction that the effectiveness of express actions not be nullified can be interpreted as prohibiting disruption of the statutory scheme. ${ }^{123}$ Moreover, the Court's willingness to invoke expressio unius in recent decisions denying implication ${ }^{124}$ may mean that it will apply the rule to preclude overlap between existing remedies. In response to the Court's restrictive attitude toward implied remedies, an increasing number of lower courts have invoked expressio unius to deny plaintiffs a cause of action under an implied action when the challenged conduct was proscribed by an express liability provision. ${ }^{125}$

The recent Supreine Court decisions, however, can also be interpreted as rejecting an exclusivity approach. In Hochfelder the Court's unwillingness to base its holding solely on its conceru that the express procedural requirement would otherwise be nullified indicates that the Court will consider other factors in determining the proper interrelationship of private rights of action. ${ }^{126}$ In Blue Chip Stamps the Court

122. See notes 117-18 supra and accompanying text.

123. See note 48 supra.

124. See Transamerica Mortgage Advisors, Inc. v. Lewis, 444 U.S. 11, 18-20 (1979); Touche Ross \& Co. v. Redington, 442 U.S. 560, 571-72 (1979); Securities Investor Protection Corp. v. Barbour, 421 U.S. 412, 420 (1975); National R.R. Passengers Corp. v. National Ass'n of R.R. Passengers, 414 U.S. 453, 458 (1974). See notes 18 \& 26 supra and accompanying text.

125. See, eg., Keaukaha Panaewa Community Ass'n v. Hawaiian Homes Comm., 588 F.2d 1216 (9th Cir. 1978) (statutory provision for public or very narrow private action raises rebuttable presumption of no legislative mtent to grant general private enforcement cause of action), cert. denied, 444 U.S. 826 (1979); Olsen v. Shell Oil Co., 561 F.2d 1178, 1184-85 (5th Cir. 1977) (no implied remedy is provided under Outer Contmental Shelf Lands Act, 10 U.S.C. $\$ \$ 7421-7426$, 7428-7438, 43 U.S.C. $\$ \S 1331-1343$ (1976), given existence of both civil and criminal remedies under the Act), cert. denied, 444 U.S. 979 (1979); Wenzer v. Consolidated Rail Corp., 464 F. Supp. 643 (E.D. Pa.), aff'd, 612 F.2d 576 (3d Cir. 1979) (specification of one remedy excludes another); Berman v. Richford Indus., Inc. [1978] Fed. SEc. L. REP. (CCH) I 96,518 at 94,012 (S.D.N.Y. 1978) (section 18(a) of Securities Exchange Act of 1934, 15 U.S.C. $\$ 78 \mathrm{r}(\mathrm{a})$ (1976), is exclusive remedy for misstatements in reports filed with SEC); Pearlstein v. Justice Mortgage Investors, [1979 Transfer Binder] FED. SEC. L. REP. (CCH) I 96,760 at 94,974-75 (N.D. Tex. 1978) (section 18(a) is exclusive); Jaillet v. Hill \& Hill, 460 F. Supp. 1075 (W.D. Pa. 1978) (no implied remedy under section 202(a) of the Water Pollution Prevention and Control Act, 33 U.S.C. § 1282(a) (Supp. II 1978); express remedy in section 505(a) of the Act, 33 U.S.C. $\$ 1365$ (1976), exclusive); Kulchok v. Government Employees Ins. Co. [1977-1978 Transfer Binder] FED. SEC. L. REP. (CCH) I 96,002 (D.D.C. 1977) (section 18(a) exclusive); Sverha v. Mathews, 408 F. Supp. 1064 (E.D. Pa. 1976) (when statute creates rights and provides specific remedy, remedy is exclusive).

126. The Court found that the statutory language and legislative history indicated no congressional intent to proscribe conduct not involving scienter. 425 U.S. at 199-202. See note 46 supra and accompanying text. See also Cox 585. 
stressed that the legislative scheme alone provided madequate guidance for ascertaining the proper contours of the section 10(b) implied right of action. ${ }^{127}$ The Court noted that actual imtent concerning the scope of a judicially created private action cannot logically be attributed to Congress merely because a statutory scheme exists. ${ }^{128}$ The Court thus looked to other factors in determining whether to extend the implied private action under section $10(\mathrm{~b})$ to nonpurchasers and nonsellers of securities. ${ }^{129}$ Recently, in Redington, the Court indicated that it will examine a statute's legislative history to determine whether an express liability section provides the exclusive remedy for the challenged conduct. ${ }^{130}$ It is clear, therefore, that the Court will not rule out the possibility of an implied private action merely because the conduct falls within the strictures of an express liability provision. Expressio unius is merely to be used as a tool of statutory construction, not as a conclusive index of legislative intent. ${ }^{131}$ The language in Hochfelder can also be interpreted as tolerating limited disruption of the statutory scheme when the effectiveness of the express liability provisions is unaffected. ${ }^{132}$ While the Court indicated that the effectiveness of the express sections inust not be impaired, it did not state-and never has stated-that all overlap between private actions must be avoided. ${ }^{133}$

Despite the increasing number of courts willing to prevent any overlap, ${ }^{134}$ raising a presumption in favor of exclusivity is a flawed approach. Expressio unius by itself is an unreliable index of congressional

127. 421 U.S. at 737.

128. Id.

129. See notes $35-42$ supra and accompanying text.

130. The Court noted in dictum that "It]here is evidence [in the legislative history of the Securities Exchange Act of 1934] to support the view that \$ 18(a) was intended to provide the exclusive remedy for misstatements contained in any reports filed with the [Securities and Exchange] Commission, including those filed pursuant to $\$ 17(\mathrm{a}) . " 442$ U.S. at 573-74.

131. In Transamerica Mortgage Advisors, Inc. v. Lewis, 444 U.S. 11, 19-22 (1979), the Court relied on expressio unius and on the legislative history in denying an implied right of action under section 206 of the Investment Advisors Act of 1940, 15 U.S.C. $\$ 80 \mathrm{~b}-6$ (1976). Similarly, in Redington, the Court used an expressio unius argument merely as support in denying an imphed right of action. 442 U.S. at 571-72.

Although courts have used the expressio unius rule for many years, they have not agreed as to its proper scope. They have used the rule to preclude implying causes of action when express remedies have been provided. See text accompanying notes 115-17 supra. The rule has also, however, been used merely as a tool of statutory construction. See Comment, supra note 118, at 1412, 1415-19. Although the Supreme Court appeared to rely on expressio unius in Amtrak, the opimion can be interpreted as using the rule to support its view that an implied action would interfere with the statutory purpose. Id. 1419. See notes 18-19 supra and accompanying text.

132. See notes $160-61$ infra.

133. Id.

134. See note 125 supra and accompanying text. 
intent and has been widely criticized. ${ }^{135}$ The rule assumes that Congress considered all possible rights of action and made a discriminating choice as to which would be allowed. This premise "usually is unrealistic, for it assumes too much foresight im the draftsman." 136 The provision of specific remedies may only reflect Congress's concern that certam rights of action be assured. ${ }^{137}$ Furthermore, carefully drawn procedural requirements in the express liability provisions should not autoinatically serve as a basis for denymg implied rights of action for the challenged conduct. The existence of particular requirements may only suggest that any implied right of action for the same statutory violation must contain requirements as rigorous as those imposed by the express liability section. Moreover, the statutory scheme in certain acts implies that some disruption is acceptable. 138 Plamtiffs are often allowed, for instance, to bring actions under different express provisions with different substantive requirements. ${ }^{139}$

The presumption of exclusivity may also ignore the purpose of a statute. This is illustrated $\mathrm{m}$ the case of implied rights of action under the Rivers and Harbors Act of 1899. ${ }^{140}$ In Sierra Club v. Morton ${ }^{141}$ the district court held that sections 9 and 10 of the Act gave rise to implied rights of action. According to the court, Congress enacted those sections to prevent mjuries to private parties as a result of obstructions to navigation unauthorized by the Umited States. ${ }^{142}$ The court rejected the claim that section $12,{ }^{143}$ which inakes violation of those sections a

135. See SEC v. C.M. Joiner Leasing Corp., 320 U.S. 344, 350 (1943); Potomac Passengers Ass'n v. Chesapeake \& O. Ry., 475 F.2d 325, $331-32$ (D.C. Cir. 1973), rev'd sub nom. National R.R. Passenger Corp. v. National Ass'n of R.R. Passengers, 414 U.S. 453 (1974); Matheson v. Armburst, 284 F.2d 670, 674 (9th Cir. 1960), cert. denied, 365 U.S. 870 (1961). See also Note, Implying Civil Remedies, supra note 2, at 290-91 (1963). Until the Supreme Court's resurrection of the expressio unius rule in Amtrak, it had not resorted to that rule of statutory construction since its decision in Botany Worsted Mills v. United States, 278 U.S. 282 (1929).

136. Durnin v. Allentown Fed. Sav. \& Loan Ass'n, 218 F. Supp. 716, 719 (E.D. Pa. 1963).

137. See Cox 601 .

138. For example, under the express liability provisions of the Securities Acts, a plaintiff may sue for a misleading report either under section 9(a)(4) of the Securities Exchange Act of 1934, 15 U.S.C. $\S 78 \mathrm{i}(a)(4)$ (1976), or under section 12(2) of the Securities Act of 1933, 15 U.S.C. $\S 77 /(2)$ (1976).

139. The statutory disruption which Congress has permitted in the case of sections 9(a)(4) and 12(2) may indicate that similar disruption between an implied and an express private action also may be permissible, provided that significant hurdles face plaintiffs under both sections. See text accompanying note 165 infra.

140. 33 U.S.C. $\$ 401$ (1976). For a discussion of recent litigation under this Act, see Comment, Sections 9 and 10 of the Rivers and Harbors Act of 1899: The Erosion of Administrative Control by Environmental Suits, 1980 DUKE L.J. 170.

141. 400 F. Supp. 610 (N.D. Cal. 1975), modified sub nom. Sierra Club v. Andrus, 610 F.2d 581 (9th Cir. 1979), cert. filed, 49 U.S.L.W. 3123 (U.S. 1980) (No. 79-1625). The Court rccently granted certiorari in Andrus's companion case. See Kern County Water Agency v. Sierra Club, 610 F.2d 581 (9th Cir. 1979), cert. granted, 49 U.S.L.W. 3245 (U.S. Oct. 7, 1980) (No. 79-1502).

142. $400 \mathrm{~F}$. Supp. at 623.

143. 33 U.S.C. $\$ 406$ (1976). 
misdemeanor and permits the Attorney General to seek an injunction to remove structures erected in violation of sections 9 and 10 , was the exclusive remedy under the Act. ${ }^{144}$ While the Morton court acknowledged the lack of clear evidence of legislative intent contrary to exclusivity in sections 9 and $10,{ }^{145}$ it found that the Supreme Court's decision in Wyandotte Transportation Co. v. United States ${ }^{146}$ precluded application of the expressio unius naxim to the Rivers and Harbors Act of 1899. Had the court followed an exclusivity approach, as urged by the Attorney General, it would have ignored the legislative purpose of preventing injuries to private parties.

4. Limited Overlap. A fourth approach some courts developed prior to the emergence of the Suprene Court's restrictive attitude was to permit limited overlap of express and imphed rights of action. Under this approach, an implied action might be used to fill a perceived gap in the statutory scheme, by permittmg plaintiffs who otherwise would be excluded by the requirements of the express liability provisions to sue under the implied cause of action. Before permitting overlap between an implied and express cause of action, however, courts taking this approach would evaluate the overlap's effect on the statutory scheme. Overlap would be permitted only when the implied private action would not undermine the express liability provision by allowing the plaintiffs to recover under the same facts, but with easier procedural or substantive requirements. Courts using this approach thus permitted a plaintiff to avoid the particular requirements of an express liability provision when to proceed under the imphed private action would still require the plaintiff to overcome other significant substantive and procedural hurdles. ${ }^{147}$ The existence of different barri-

144. 400 F. Supp. at $624-25$.

145. Id. at 623 n. 10.

146. 389 U.S. 191 (1967).

147. See, e.g., Stewart v. Bennett, 359 F. Supp. 878, 884 (D. Mass. 1973) (implied action under section 10 (b) for misrepresentations in registration statement and prospectus is permitted although section 11 of Securities Act of 1933 covers such conduct; more stringent procedural restrictions under section 11 are balanced by requirement of section 10(b) that plaintiff show fraud); Dorfman v. First Boston Corp., 336 F. Supp. 1089, $1093-96$ (E.D. Pa. 1972) (implied action found under section 17(a) of 1933 Securities Act for misstatements despite express provision in section 12(2) because stricter procedural requirements of section 12(2) are balanced by section 17(a) proof of fraud requirement).

Implicit in the limited overlap approach is the view that free overlap would be overly disruptive of the legislative scheme. See Stewart v. Bennett, 359 F. Supp. at 883-84. Courts have also used this approach of carefully appraising the extent of the disruption resulting from overlap when those express liability provisions in an act provide for administrative enforcement. See, e.g., Network Project v. Corporation for Pub. Broadcasting, 561 F.2d 963, 974-75 (D.C. Cir. 1977) (implication of rights of action should be approached with great care lest a carefully erected legislative scheme be skewed; private actions under Public Broadcasting Act of 1967 are contrary to balanced framework of administrative enforcement), cert. denied, 434 U.S. 1068 (1978). 
ers under the implied right of action meant that often it would be advantageous or necessary for plaintiffs to sue under the express section, thereby preventing plaintiffs from routmely bypassing the particular requirements of the express liability provisions by suing under an implied right of action.

Courts permitting limited overlap liave einpliasized differences in procedural requirements, burden of proof, measure of damages, and elements of a prima facie case. ${ }^{148}$ In Fischman v. Raytheon Manufacturing Co. ${ }^{149}$ the Court of Appeals for the Second Circuit employed a limited overlap approach to permit suit under section 10(b) and rule $10 \mathrm{~b}-5$ even though section 11 of the Securities Act of $1933^{150}$ also prohibited the challenged conduct. The court allowed the action because section $10(\mathrm{~b})$ required the plaintiff to show fraud, a substantive requireinent not present in section 11. Thus, altlough the plaintiff was able to avoid the procedural requirements of section 11, lie faced a significantly greater burden of proof under section 10(b)..$^{151}$

Many courts have continued to follow the limited overlap approach simce the beginning of the Supreme Court's restrictive policy toward implied remedies. ${ }^{152}$ In Ross v. A.H. Robins Co., ${ }^{153}$ the Court

148. See, e.g., Cook v. Avien, Inc., 573 F.2d 685 (1st Cir. 1978) (section 12(2) action requires mere proof of negligent omissions, though statute of limitations for section 10 (b) action is longer); Sanders v. John Nuveen \& Co., 554 F.2d 790 (7th Cir. 1977) (implied private action under section 17(a) of Securities Act of 1933, 15 U.S.C. $\$ 77 q(a)$ (1976), contains scienter requirement; express rights of action in contrast impose different substantive and procedural restrictions); Pearlstcin v. Justice Mortgage Investors, [1978-1979] FED. SEC. L. REP. (CCH) ๆ 96,760 at 94,974-75 (N.D. Tex. 1978) (scienter requirement of section 10(b) distimguishes that cause of action from those under sections 11 and 12 of the Securities Act of 1933); Dorfman v. First Boston Corp., 336 F. Supp. 1089, 1093-96 (E.D. Pa. 1972) (implied action under section 17(a) of Securities Act of 1933 requiring proof of fraud distmguished from express action under section 12(2)).

149. 188 F.2d 783 (2d Cir. 1951).

150. 15 U.S.C. $\$ 77 \mathrm{k}(1976)$.

151. 188 F.2d at 786. Section 11 subjects a plaintiff to a shorter statute of limitations than section $10(\mathrm{~b})$ and to a bonding requirement not present in the implied right of action. See notes 85-86 supra and accompanying text.

152. See, e.g., Cook v. Avien, 1nc., 573 F.2d 685, 692-94 (1st Cir. 1978) (private action under sections 10(b) of 1934 Act and 12(2) of 1933 Act compared; 10(b) requires scientcr, 12(2) has stricter procedural requirements); Sanders v. John Nuveen \& Co., 554 F.2d 790, 795 (7th Cir. 1977) (implied right of action under section 17(a) of 1933 Act requires scienter so as not to negate procedural restrictions of sections 11 and 12(2) of 1933 Act); Pearlstein v. Justice Mortgage Investors, [current] FED. SEC. L. REP. (CCH) ๆ 96,760 at 94,974-75 (N.D. Tex. 1978) (scienter requirement of section 10(b) action distinguislses it from sections 11 and 12(2) of 1933 Act); Piascik v. Cleveland Museum of Art, 426 F. Supp. 779, 780-81 n.1 (N.D. Olio 1976) (although implied right of action under section 90(a), Emergency School Aid Act, 20 U.S.C. $\$ \S$ 1601-1619 (1976), would duplicate an express remedy in Title VII of Civil Rights Act of 1964,42 U.S.C. $\$ \S 2000 \mathrm{e}$ to $2000 \mathrm{e}$ 17 (1976), implied remedy is necessary to effectuate congressional purpose of assuring equal educational opportumity).

153. 607 F.2d 545 (2d Cir. 1979), cert. denied, 100 S. Ct. 2175 (1980). 
of Appeals for the Second Circuit followed its approach in Fischman, finding an implied cause of action under section 10(b) for damages caused by the filing of false and misleading information with the Securities and Exchange Commission, notwithstanding that section 18(a) of the Securities Exchange Act ${ }^{154}$ prohibited the same conduct. The Ross court rejected the view that implied and express private actions may coexist without restraint, noting the Supreme Court's recent concern for preserving the statutory scheme. ${ }^{155}$ Permitting the plaintiff to sue under section $10(\mathrm{~b})$, however, would not nullify the terms of section 18(a). The court observed that while section 18(a) imposes unuch stricter procedural requirements than section $10(\mathrm{~b})$, plaintiffs proceeding under the latter section face a significantly greater burden of proof. A plaintiff suing under section 10(b) must plead and prove that the defendant acted with scienter in making a material misrepresentation or omission. Under section 18(a), by comparison, a plaintiff is required only to show reliance on the misstatement. ${ }^{156}$

The Ross court reasoned that permitting suit under section 10(b) furthered a fundamental securities law policy of protectimg open market investors. ${ }^{157}$ Section 10 (b) and rule $10 \mathrm{~b}-5$ are the primary mechanisms of redress under the securities laws for open market investors. According to the court:

To hold now, at this late date, that conduct is not proscribed by section 10 (b) merely because it is also subject to section 18 would effectively deprive open market investors who relied on misleading market information of any remedy simply because the mismformation happened to be lodged in a form with the S.E.C. ${ }^{158}$

The Supreme Court's language in Blue Chip Stamps, Hochfelder, and Redington ${ }^{159}$ supports the Second Circuit's approach in Ross. None of the Supreme Court cases discussed whether overlap between express and implied remedies should be permitted. The language regarding harmonization in each decision ${ }^{160}$ is significant, however, because it cautions that the effectiveness and the purpose of the substantive and procedural restrictions of the express liability provisions should not be nullified. Limited disruption of the statutory scheme that does not negate the express requirements of those sections

154. 15 U.S.C. $\S 78 \mathrm{r}(\mathrm{a})$ (1976).

155. 607 F.2d at 554.

156. Id. at 555-56. See note 63 supra and accompanying text.

157. 607 F.2d at 556.

158. Id.

159. See notes 28-48 supra and accompanying text.

160. See notes 31-34 \& 40-48 supra and accompanying text. 
and is not inconsistent with the probable legislative intent would be permissible. ${ }^{161}$

In short, the himited overlap approach is the preferable harmonizing method for several reasons. First, limited overlap is restrictive and thus consistent with recent Supreme Court decisions in the area of implied reinedies. Second, the approach implements the Court's insistence that implied actions should not undermine the specific requirements of the express liability provisions. ${ }^{162}$ Third, limited overlap effectuates the probable legislative intent better than the other approaches. This is likely to be important in view of the Supreme Court's einphasis on discerning legislative intent. ${ }^{163}$ The limited overlap approach recognizes that some disruption may be consistent with Congress's intentions, considering that Congress sometimes expressly creates overlap in the statutory scheine. ${ }^{164}$ Moreover, the imposition of significant burdens on plaintiffs suing under an implied cause of action furthers the apparent congressional policy of preventing vexatious or frivolous litigation by requiring plaintiffs to overcome significant barriers. ${ }^{165}$ As Professor Loss has noted, Congress included significant procedural restrictions in the express hability provisions of the securities acts as a barrier to be overcome by plaintiffs seeking to sue under the express private rights of action. ${ }^{166}$ Limited overlap would effectuate this policy by imposing significant restrictions on plaintiffs seeking to sue for particular statutory violations. ${ }^{167}$ Finally, the limited overlap approach may be necessary to effectuate the overall goals of a particu-

161. Ultimately, the extent to which the Supreme Court will allow implied rights of action to overlap with express actions is probably directly dependent upon the Court's theory for implying private rights of action. Thus, if the Court's theory for implying private rights of action continues to be based upon a presumed intention of Congress, the overlap may well be limited to finding another presumed intention of Congress as to the extent of permissible overlap. If, on the other hand, the Court were to shift back to the Borak rationale of determining what would best further the legislative purpose, overlap would be permitted to best effectuate the legislative purpose and presumably would be more extensive.

162. See notes 31-48 supra and accompanying text.

163. See notes 21-27 \& 50 supra and accompanying text.

164. See text accompanying note 111 supra.

165. See Blue Chip Stamps v. Manor Drug Stores, 421 U.S. 723, 737 (1975). See note 51 supra.

166. III L. Loss, supra note 88 , at 1780.

167. Professor Loss did express doubts whether courts should "attribute to Congress the rather elaborate intention" that a plaintiff be permitted to avoid the procedural requirements of the express liability provisions "if he voluntarily elects to assume the burden of [proving scienter] on an issue." Id. 1786. The important inquiry, however, is not to determine what specific restrictions Congress intended, but rather how difficult Congress intended suits for particular inisconduct to be. As Professor Loss notes, the fear of "strike suits" led Congress to amend section $11(e)$ of the Securities Act of 1933 to provide both for security and for the award of counsel fees. Id. 1837. Equally stringent restrictions under an implied right of action would be consistent with the legislative intent of preventing vexatious litigation. 
lar federal act. For example, in Ross a refusal to allow overlap would have hindered the fundamental securities law objective of protecting open market investors. ${ }^{168}$

\section{B. Unresolved Issues in Implementing the Limited Overlap Approach.}

Despite the appeal of the limited overlap approach, there are a number of unresolved questions concerning its implementation. A principal problem is that the approach does not provide standards to determine what constitutes sufficiently stringent requirements under an implied remedy to assure that restrictions included in the express hability provision will not be nullified. Without standards, the balancing of substantive and procedural hurdles might often be arbitrary and lead to nonuniform results, especially when there is hittle useful precedent. Some courts might contimue to impose less stringent requirements on the implied rights of action, thus permitting plaintiffs to avoid restrictive express liability provisions. A second problem is that a limited overlap scheme does not indicate how courts should determine the procedural and substantive requirements to be imposed on plaintiffs sumg under an implied private action. The problem becomes magnified when courts must decide whether to impose additional restrictions on an implied action previously found to be excessively disruptive of the statutory scheme. ${ }^{169}$ Finally, there may be some circumstances in which the limited overlap approach may not even be used.

1. Standards for Determining the Adequacy of Restrictions on Implied Private Actions. There are a number of possible standards which courts could use to determine if the substantive or procedural requireinents imposed on plaintiffs suing under an implied action are significant enough to warrant avoidance of the particular restrictions in the express provision. One such standard would require that the restrictions imposed on plaintiffs suing under the implied private action be as stringent as or more stringent than those imcluded in the express habil-

168. See note 158 supra and accompanying text.

169. One element of the section $10(b)$ action that might excessively disrupt the statutory scheme is the coupling of permissive causation requirements with a longer statute of limitations than exists under the express liability provisions of the securities laws. One commentator has suggested that this development may be contrary to the likely legislative objective of preventimg a defendant's misleading statement or manipulative conduct from establishing him as an insurer of the enterprise's success. Cox 612-13. Professor Cox argues that the coupling of hiberal causation rules with short statutes of limitations in the express hability provisions is persuasive evidence of this congressional objective. Id. 611-12. To prevent plaintiffs from frustrating the pohicy of the carefully drawn express liability provisions, courts may thus be forced to choose between more stringent causation rules or sliorter statutes of limitations. See notes 174-75 infra and accompanying text. 
ity provision. Thus, when different substantive requirements are involved, courts would determine whether the burden of proving the elements of the implied action is as great as the burden facing plaintiffs under the express liability section. In Ross v. A.H. Robins Co. ${ }^{170}$ the court relied im part on this type of analysis, finding that "the far more difficult task [proof of scienter] which confronts a plamtiff seeking to proceed under $\S 10$ (b) provides a rationale for dispensing with the rehance requirement inherent im $\S 18 . " 171$

Nevertheless, permitting overlap solely on the basis of the rigorousness of hurdles facing plaintiffs under each right of action wrongly assumes that the purpose of substantive and procedural requireinents is solely to restrict the ease with which plaintiffs may sue for a particular statutory violation. This assumption ignores the fact that significant qualitative differences between the eleinents of the private actions alone may be sufficient to preserve the effectiveness of the express hability provisions. Plamtiffs unable to prove an element necessary for an implied right of action, for exainple, have no alternative but to try to proceed under the express private action. ${ }^{172}$ The fact that the requirements of the implied action might be less burdensome on the plaimtiffs would not, under those circumstances, detract from the effectiveness of the express liability section. In addition, the rigorousness standard would be difficult to impleinent. Comparing the relative burdens facing plaimtiffs under each right of action is largely a speculative exercise, and could lead to arbitrary decisions allowing or disallowing the implied cause of action.

A second possible standard would be to perinit suit under an implied private action whenever the imphed action imposes substantive requirements different from those imposed under the express liability provisions. The addition of different elements may indicate that the implied action addresses different problems arising out of the particular federal act. Arguably, the generally narrow scope of the express hability provisions gives rise to the inference that the restrictions included are therefore mapplicable to statutory violations outside of the limited scope of the express sections. The disadvantage of this standard is that it is too simplistic. By allowing overlap when there is any difference $m$ substantive requirements, courts may permit plaintiffs to continue to avoid the express provisions by alleging additional facts which might be relatively imsignificant. Furthermore, this approach ignores the pos-

170. 607 F.2d 545 (2d Cir. 1979), cert. denied, 100 S. Ct. 2175 (1980).

171. 607 F.2d at 556 .

172. Plaintiffs unable to prove scienter in the filing of misleading docuinents inust therefore proceed under section 18(a)'s express right of action. 15 U.S.C. \&78r(a) (1976). 
sible congressional policy of imposing strenuous procedural restrictions on all private actions involving the same type of statutory violation. ${ }^{173}$

A better standard would require courts to examine the restrictions imposed on each right of action and assess the likely impact of permitting the implied action on the future use of the express right of action. Under this standard, overlap would be acceptable in two general situations. First, overlap would be acceptable when, consistent with the congressional policy embodied in the express provision, each right of action presented its own distinct procedural or substantive advantages. Thus, although a class of plaintiffs might be able to sue under either the express or the implied action, that class could not consistently choose to bring suit under the latter. For example, a section 10(b) implied right of action witl delnanding causation requirements, ${ }^{174}$ but with a long statute of himitations, could overlap with an express right of action with liberal causation rules and a short statute of limitations. The policy underlying the restrictions on each cause of action would be the same: to prevent the defendant's misconduct from establishing him as an insurer of the enterprise's success. 175 While proceeding under the implied action miglit allow soine plaintiffs to sue who would otherwise be precluded from bringing suit, other plaintiffs would find it advantageous to bring a timely action under the express provision and avoid the strenuous causation requirements.

The second situation in which courts would permit overlap would be when each private action is available only in limited circumstances, so that a class of plaintiffs would be unable to sue under an implied private action in order to avoid the restriction included in the express provision. In Dorfman v. First Boston Corp., ${ }^{176}$ a decision involving section 17 (a) ${ }^{177}$ and 12(2) ${ }^{178}$ of the Securities Act of 1933, the court took a similar approach. In that case, the court found an implied right

173. See notes 166-67 supra and accompanying text.

174. Under the federal securities laws, causation may consist of two separate inquiries: (l) did the challenged conduct prompt the plaintiff to purchase or sell a security (transaction causation); and (2) did the economic loss suffered by the plaintiff result from the defendant's wrongdoing (loss causation). Cox 611. Courts have held that the implied action under section 10(b) imposes permissive causation requirements. See, e.g., Blackie v. Barrack, 524 F.2d 891, 906 (9th Cir. 1975) (proof of purchase of shares and of materiality of misrepresentations establishes causational chain between defendant's conduct and plaintiff's loss to make out prima facie case); Zipkin v. Genesco, Inc. [1975-1976 Transfer Binder] FED. SEC. L. REP. (CCH) If 95,409 (S.D.N.Y. 1975) (presumption of causation). See also Cox 618. The section 10(b) action combination of permissive causation rules with a long statute of limitations may require reevaluation in light of the Supreme Court's concern for the statutory scheme. See note 169 supra and accompanying text.

175. See note 169 supra and accounpanying text.

176. 336 F. Supp. 1089 (E.D. Pa. 1972).

177. I5 U.S.C. $\$ 77 q(a)(1976)$.

178. 15 U.S.C. $\& 77 /(2)$ (1976). 
of action under provisions of section 17(a) proscribing fraud in the sale or offering of securities. The court declined to impose the specific procedural requirements of the section 12(2) express right of action, which permits suit to be brought for innocent or neghigent misstatements in connection with prospectuses and communications. According to the court, the requirement of proof of fraud in the section 17(a) implied cause of action distinguished it from the action expressly provided by section 12. There was therefore "no justification for implymg the limitations of $\S 12$ " into the implied private action. ${ }^{179}$

2. Determining Substantive and Procedural Requirements for Implied Private Actions. A second unresolved issue under the limited overlap approach concerns low courts should determine which restrictions to inpose on plaintiffs suing under an implied private action.

(a) Substantive restrictions. Before deciding which substantive restrictions to impose, courts first should discern the legislative intent regarding the elements of the particular implied private right of action. This approach appears to be required by the Supreme Court's policy that private rights of action not be implied or expanded unless Congress so intended. ${ }^{180}$ However, though Congress may have given con-

179. 336 F. Supp. at 1095 .

180. See notes 18-21 \& 50 supra and accompanying text. In this regard, a question arises whether courts inust also reexamine procedural and substantive requirements that have already been included in implied actions to determine if they are consistent with the perceived legislative intent. Hochfelder implies that reexamination is required. The court evaluated the section 10 (b) implied private action it had previously recognized in Superintendent of Ins. v. Bankers Life \& Cas. Co., 404 U.S. 6 (1971), to determine if Congress intended to require scienter. 425 U.S. at I9697. A further question is whether courts should elimimate existing implied rights of action if they are found to be contrary to the Court's imterpretation of the likely legislative intent. No lower court lias gone this far. Instead, the courts generally have accepted private actions that they have previously implied without inquiring into their consistency with the legislative intent. See, c.g., Ross v. A.H. Robims Co., 607 F.2d 545 (2d Cir. 1979) (Supreme Court decisions establishing tests for implication inapposite when action already has been implied), cert. denied, $100 \mathrm{~S}$. Ct. 2175 (1980); Hughes v. Dempsey-Tegeler \& Co., 534 F.2d 156, 166 n.5 (9th Cir. 1976) (Supreme Court's decisions do not mandate elimmation of longstanding private action under section 6 of the 1934 Securities Exchange Act); Smith v. Groover, 468 F. Supp. 105, 112 (N.D. Ill. 1979) (recognized implied action sliould not be subjected to Cort test every time the action is litigated). But $c f$. Brotherliood of Ry. Airline \& S.S. Clerks v. Philadelphia B. \& N.E. Ry. Co., 428 F. Supp. 1308, 131 1-12 (E.D. Pa. 1977) (precedent of finding implied action under Railway Labor Act followcd with reservations; action liad been inferred before the Cort and Piper decisions).

The Supreme Court is unlikely to elimmate existing implied remedies. For example, it has distinguished its Borak decision, permitting the implied action under section 14(a) of the 1934 Securities Exchange Act to stand. See Touche Ross \& Co. v. Redington, 442 U.S. 560 (1979) ("Since Borak we liave adhered to a stricter standard for the implication of private causes of action"). Nonetheless, precedent exists for the Court to eliminate an existing implied remedy: in Moore v. Cliesapeake \& O. Ry., 291 U.S. 205 (1934), the Supreme Court overruled Texas \& Pac. Ry. v. Rigsby, 241 U.S. 33 (1916), holding that the Federal Safety Apphance Act, 45 U.S.C. $\$ 8$ 1- 
sideration to the desirable requirements of a possible imphed private action, there may be little direct evidence of legislative intent regarding the substantive restrictions to be imposed. ${ }^{181}$ Nonetheless, the Supreme Court has indicated that reliable legislative imtent regardimg an implied action "may appear imphicitly in the language or structure of the statute, or in the circumstances of its enactment." 182

Courts traditionally liave discerned legislative intent from three specific sources. They have looked first to the statutory language. ${ }^{183}$ The particular conduct proscribed in the provision giving rise to the implied private action thus indicates the necessary elements of that action. In Dorfman v. First Boston Corp. ${ }^{184}$ for example, the court found that fraud was a necessary element of the section 17(a) imphed cause of action in view of the plain language prohibiting fraudulent conduct in the statute. ${ }^{185}$ When the statutory language madequately indicates the underlying intent of Congress, courts have also looked to the legislative history of the particular statute. ${ }^{186}$ Despite the frequency with which this is done, however, courts should avoid placing too mucli reliance upon the often equivocal evidence of intent found in the legislative history. Such evidence inay not be conclusive of the general sentiment of Congress or may be subject to different interpretations; it is, therefore, an unrehable indicator of congressional intent. ${ }^{187}$ Nonetheless, the Supreme Court has demonstrated in its recent decisions that it will rely on the legislative history to determine the legislative intent. ${ }^{188}$ Courts

7, 11-15 (1976), no longer serves as the basis of an implied civil action. See H.M. HART \& H. Wechsler, The Federal Courts and the Federal System 798-806 (2d ed. 1973); Note, Emerging Standards, supra note 2, at 285. See note 3 supra and accompanying text.

181. See Transamerica Mortgage Advisors, Inc. v. Lewis, 444 U.S. 11, 18 (1979) (silence in legislative history regarding imphed action not surprising where no express action provided); Comment, supra note 118 , at 1413. Solne commentators have criticized as futile the search for evidence to determine if Congress contemplated resort to private actions without providing for such actions in the statute. Id. 1412; 61 HARv. L. REv. 858, 860 (1948). Insofar as implication assumes that Congress did not specifically perceive the need for the implied remedy when it enacted the statute, efforts to discover specific intent to create the remedy are misdirected. Coinment, supra note 118, at 1413.

182. Transamerica Mortgage Advisors, Inc. v. Lewis, 444 U.S. 11, 18 (I979).

183. Id. at 16 .

184. 336 F. Supp. 1089 (E.D. Pa. 1972).

185. Id. at 1095 .

186. A. SuTHERLAND, supra note $97, \S 4506$ at 322.

187. Comment, supra note 118, at 1414. One court warned: "Courts sliould avoid delving into 'legislative history which, through strained processes of deduction from events of wholly ambiguous significance, may furnish dubious bases for inference in every direction.' " Potomac Passengers Ass'n v. Chesapeake \& O. Ry., 475 F.2d 325, 335 (D.C. Cir. 1973) (quoting Gemsco, Inc. v. Walling, 324 U.S. 244, 260 (1945)), rev'd sub nom. National R.R. Passenger Corp. v. National Ass'n of R.R. Passengers, 414 U.S. 453 (1974).

188. See notes 25-26 supra and accompanying text. 
have also looked to the elements of related provisions in the same statute or set of statutes to determine which substantive requirements Congress intended to include in an implied right of action. The theory behind this analysis is that if Congress worded two statutes similarly or directed each to the same conduct it is reasonable to infer that Congress wanted the statutes' implied actions to have the same substantive requirements. ${ }^{189}$ A proininent example of this reasoning is the section 17(a) ${ }^{190}$ implied action, which some courts ${ }^{191}$ have patterned closely after the rule $10 \mathrm{~b}-5$ action. ${ }^{192}$ In light of the almost identical language of the two provisions, courts have extended most of the substantive requirements of the $10 \mathrm{~b}-5$ action to the section 17(a) private action. ${ }^{193}$ It thus has been held that the imphed action under section 17(a) requires that the plamtiffs prove scienter. ${ }^{194}$ Resort to one or more of these sources will permit courts to fashion substantive requirements for implied rights of action which coinport with the likely legislative intent.

(b) Procedural restrictions. When a court is determining what procedural requirements to inpose under an implied private action, littIe is gained by searching for evidence of legislative intent. If Congress did not botlier to expressly provide for a private right of action, it is unlikely to liave considered what procedural restrictions would be desirable in the event a court implied a private right of action. Instead, courts traditionally have looked to state law ${ }^{195}$ and to the restrictions contaimed in related express hability sections ${ }^{196}$ as guides in formulating the procedural requirements for implied rights of action. While these may continue to serve as useful models, courts should avoid construing express and implied rights of action in pari materia, whereby all

189. See A. SuTHERLAND, supra note $97, \S 4507$ at 323-24.

190. 15 U.S.C. $\$ 77 q(a)(1976)$.

191. See cases cited in note 193 infra.

192. 17 C.F.R. $§ 240.10$ b-5 (1980).

193. See Sanders v. John Nuveen \& Co., 554 F.2d 790 (7th Cir. 1977) (section 17(a) requires scienter); accord, Marrero v. Abraham, 473 F. Supp. 1271 (W.D. La. 1979). See generally Hazen, supra note 66 , at $646-47$.

194. See note 193 supra and accompanying text.

195. Thus, the courts have applied the analogous limitation period of state law to section $10(\mathrm{~b})$ and rule 10b-5 actions under Hohnberg v. Armbrecht, 327 U.S. 392 (1946). See, e.g., Parrent v. Midwest Rug Mills, lnc., 455 F.2d 123 (7th Cir. 1972) (statute of limitation period for negligence actions apphed to section 10(b) actions); Vanderboom v. Sexton, 422 F.2d 1233 (8th Cir. 1970) (two-year state Blue Sky Law limitation applied to state 10(b) action, instead of three-year limitation under general federal fraud law). See Cox 610 .

196. See, e.g., Dorfman v. First Boston Corp., 336 F. Supp. 1089, 1095 (E.D. Pa. 1972) (procedural restrictions of sections 11 and $12(2)$ express rights of action applied to portion of section 17(a) implied action not imcluding fraud requirement). 
of the restrictions of the express provisions automatically would be incorporated into the imphed private action. ${ }^{197}$

3. Preclusion of All Overlap. A final unresolved question is whether there are situations in which courts cannot use the limited overlap approach. Arguably, courts may always be able to fashion some substantive and procedural restrictions for implied private actions which would preserve the effectiveness of the competing express liability provisions. Hence, some overlap between express and implied actions would always be permissible. The Supreme Court's recent decisions, however, require courts to disallow overlap when there is evidence that Congress provided the express liability provision as the exclusive remedy for the particular statutory violation. In Redington, for example, the Court found evidence in the legislative history of section 18(a) of the Securities Exchange Act indicating that Congress may have intended that section to provide the exclusive reinedy for misstatements contained in reports filed with the Securities and Exchange Commission. ${ }^{198}$ While the Court in Redington did not decide whether section 18(a) was exclusive, it did indicate that courts should, as a threshold matter, determine whether Congress intended the express liability provision in question to provide an exclusive remedy. When it can reasonably be inferred that Congress intended an express action to be exclusive, no overlap should be permitted.

\section{CONCLUSION}

Courts atteinpting to ascertain the proper interrelationship of private rights of action are confronted with a series of Supreme Court decisions that leave more questions unresolved than answered. Although the courts clearly must adopt an approach that avoids nullifying the effectiveness of express hability provisions included in a federal statute, the Supreme Court has not indicated the extent to which disruption of the statutory scliene is permissible. The suggested appoach to harmonization recognizes that some disruption may be acceptable and permits limited overlap between express and imphed private rights of action. Courts inust determine whether those substantive and procedural requirements imposed on plaintiffs suing under the implied cause of action are sufficient to prevent the nullification of the restrictions included in the express provision. When the substantive elements of an implied action have not yet been estabhished or when additional substantive liurdles are necessary to avoid serious disruption of the statu-

197. See notes 111-114 supra and accompanying text.

198. Touche Ross \& Co. v. Redington, 442 U.S. 560, 573-74 (1979). 
tory scheme, courts should determine the probable intent of the legislators who enacted the particular statute. This approach is in line with the Supreme Court's restrictive attitude toward the expansion of implied rights of action. Finally, the Court's recent decisions also require that lower courts determine whether the express rights of action in a particular federal act were intended to provide the exclusive reinedy for the particular statutory violation. When no clear evidence indicates exclusivity, courts may focus on the likely impact of pernitting overlap upon the statutory scheme.

Patrick B. Fazzone 